\title{
A Receptor-Mediated Mechanism of Nicotine Toxicity in Oral Keratinocytes
}

\author{
Juan Arredondo, Vu Thuong Nguyen, Alexander I. Chernyavsky, David L. Jolkovsky, \\ Kent E. Pinkerton, and Sergei A. Grando \\ Department of Dermatology (JA, VTN, AIC, SAG), School of Medicine, University of California, Davis; Section of \\ Periodontics (DLJ), School of Dentistry, University of California, Los Angeles; and Institute of Toxicology and \\ Environmental Health (KEP), University of California, Davis, California
}

\begin{abstract}
SUMMARY: Smoking and smokeless tobacco cause morbidity that originates from the epithelium lining of the skin and upper digestive tract. Oral keratinocytes (OKC) express nicotinic acetylcholine receptors (nAChRs) that bind nicotine (Nic). We studied the mechanism of the receptor-mediated toxicity of tobacco products on OKC. Preincubation of normal human OKC with Nic altered the ligand-binding kinetics of their nAChRs, suggesting that the nAChRs underwent structural changes. This hypothesis was confirmed by the finding that exposure of OKC to Nic causes transcriptional and translational changes. Through RT-PCR and immunoblotting, we found a 1.5- to 2.9-fold increase in the mRNA and protein levels of $\alpha 3, \alpha 5, \alpha 7, \beta 2$, and $\beta 4$ nAChR subunits. Exposure of OKC to Nic also changed the mRNA and protein levels of the cell cycle and cell differentiation markers Ki-67, PCNA, p21, cyclin D1, p53, filaggrin, loricrin, and cytokeratins 1 and 10. The nicotinic antagonist mecamylamine prevented these changes, which indicates that the Nic-induced changes in the expression of both the nAChR and the cell cycle and cell differentiation genes resulted from pharmacologic stimulation of nAChRs with Nic. To establish the relevance of these findings to the pathobiologic effects of tobacco products in vivo, we studied the above parameters in the oral tissue of rats and mice after their exposure for 3 weeks to environmental cigarette smoke or drinking water containing equivalent concentrations of Nic that are pathophysiologically relevant. The changes of the nAChRs and the cell cycle and cell differentiation genes were similar to those found in vitro. The results of indirect immunofluorescence assay of tissue specimens validated these findings. Thus, some pathobiologic effects of tobacco products in oral tissues may stem from Nic-induced alterations of the structure and function of keratinocyte $\mathrm{nAChRs}$ responsible for the physiologic regulation of the cell cycle by the cytotransmitter acetylcholine. (Lab Invest 2001, 81:1653-1668).
\end{abstract}

$T$ he epithelial cells lining human attached gingiva and the upper two-thirds portion of the esophagus have recently been shown to express cholinergic enzymes and receptors that mediate acetylcholine (ACh) signaling (Nguyen et al, 2000a, 2000b). The cholinergic system of oral epithelium includes the synthesizing enzyme choline acetyltransferase, two molecular forms of the degrading enzyme acetylcholinesterase, the asymmetric and the globular forms, and two classes of ACh receptors, the nicotinic and the muscarinic receptors. The heteromeric nicotinic ACh receptor ( $\mathrm{nAChRs)}$ channels on the cell membrane of oral keratinocytes (OKC) can be composed of $\alpha 3, \alpha 5, \beta 2$, and $\beta 4$ subunits, eg, $\alpha 3 \beta 2(\beta 4) \pm \alpha 5$, and the homomeric channels can be made of several $\alpha 7$ or $\alpha 9$ subunits (Conti-Tronconi et al, 1994). The diversity of $\mathrm{nAChRs}$ expressed by OKC in the course of their

Received July 26, 2001.

This work was supported in part by a research grant (No. 0713) from the Smokeless Tobacco Research Council, Inc., New York, New York (to SAG), and by research grants (Nos. 6RT-0327 and 7RT-0118) from the TobaccoRelated Disease Research Program, University of California, Oakland, California (to KEP).

Address reprint requests to: Dr. Sergei A. Grando, Department of Dermatology, University of California Davis Medical Center, 4860 Y Street, Suite \#3400, Sacramento, California 95817. E-mail: sagrando@ucdavis.edu development could allow a single cytotransmitter ACh to exert different effects on these cells at various stages of their development, which helps explain the plethora of biological effects of ACh on the stratified squamous epithelium (Grando, 1997). This novel nonneuronal cholinergic system of the oral epithelium may target OKC for the direct effects of nicotine (Nic), thus providing an additional mechanism for tobaccoinduced morbidity in the upper digestive tract. Although tobacco smoke contains over 3000 chemicals, it has been proposed that Nic is one of the key constituents causing adverse health effects (Benowitz, 1986, 1997; Benowitz and Gourlay, 1997; Zevin et al, 1998) and that Nic replacement products may also be harmful (Grady, 1998).

Nic replacement therapy is now widely used to aid tobacco cessation, and most of these products, ie, chewing gum, nasal spray and inhaler, involve absorption of Nic through the mucosa. Unfortunately, little is known about the direct effects of Nic on the mucosal epithelium, and the safety of replacement therapy has yet to be determined. Nic, acting through the nAChRs expressed by nonneuronal cells, has recently emerged as a candidate for the major pathogenic factor in tobacco-related morbidity because it exhibits a regulatory role in the biological processes which are intimately connected with each other, including cell 
growth, motility, and differentiation (Heeschen et al, 2001). Although it has been reported that Nic directly affects OKC (Chen et al, 1994; Hall et al, 1984; Ringdahl et al, 1997), the kind of cellular alterations and the biochemical pathways mediating the effect of $\mathrm{Nic}$ remain unclear. Simultaneous exposure to $\mathrm{Nic}$ and hyperoxia causes tumors in hamsters, and antagonists of nAChRs inhibit this process (Schuller et al, 1995). This suggests that chronic stimulation of nAChRs on the epithelial cell membrane in an environment of impaired oxygenation contributes to the carcinogenic burden associated with exposure to tobacco products (Schuller et al, 1995). Indeed, it has been demonstrated that pure Nic dramatically alters both keratinocyte kinetics and differentiation (Grando et al, 1996; Kwon et al, 1999; Zia et al, 2000), which are associated with an increased transmembrane $\mathrm{Ca}^{2+}$ influx and intracellular levels and could be blocked or attenuated in the presence of mecamylamine (Mec) (Grando et al, 1996).

The normal functioning of the keratinocyte ACh axis may be altered in tobacco users because Nic alters both the amount and composition of nAChRs. Previously, we reported that the repertoire of nAChRs in the respiratory epithelium of chronic smokers is significantly different from that in nonsmokers and that the changes can be reproduced in cultures of bronchial epithelial cells exposed to $10 \mu \mathrm{M} \mathrm{Nic} \mathrm{(Zia} \mathrm{et} \mathrm{al,} \mathrm{1997).}$ The goal of this study was to correlate the effects of $\mathrm{Nic}$ and tobacco products on the cell cycle and cell differentiation of OKC with the effects on the structure of nAChRs in these cells. We hypothesized that the pathobiologic effects of tobacco products in the stratified squamous epithelium stem, at least in part, from alterations in the structure and function of the keratinocyte cholinergic system caused by chronic stimulation with Nic.

We found that the exposure of normal human OKC to Nic alters the ligand-binding kinetics of their nAChRs, suggesting structural changes of the receptors. The changes were found at both the transcriptional and translational levels. Through RT-PCR and Western blotting, we detected a 1.5- to 2.9-fold increase of mRNA and protein levels of $\alpha 3, \alpha 5, \alpha 7, \beta 2$, and $\beta 4 \mathrm{nAChR}$ subunits. Exposure of OKC to Nic also changed the mRNA and protein levels of Ki-67, PCNA, p21, cyclin D1, p53, cytokeratin (CK) 1, CK 10, filaggrin, and loricrin. Aqueous extract of smokeless tobacco (AEST) produced similar changes. Mec could prevent these alterations, indicating that $\mathrm{Nic}$-induced changes in the expression of both the nAChR and the cell cycle and cell differentiation genes resulted from a pharmacologic stimulation of nAChRs. To establish the relevance of these findings for the pathobiologic effects of tobacco products in vivo, we studied the oral tissue of rats and mice after their exposures for 3 weeks to environmental tobacco smoke (ETS) or drinking water containing an equivalent concentration of Nic. The changes in nAChRs, cell cycle progression, and cell differentiation were similar to those found in vitro, and results obtained in indirect immunofluorescence (IIF) assay of tissue specimens confirmed these findings. Thus, some of the pathobiologic effects of tobacco products on the oral tissue may stem from Nic-induced alterations of the structure and function of nAChRs that alter the physiologic regulation of the unfolding of the genetically-determined program of cell development, leading to an early and excessive squamatization of the stratified epithelium. Taken together, these observations may shed light on the mechanisms which lead to precancerous lesions in tobacco users.

\section{Results}

\section{Nic Alters nAChR Number and Binding Kinetics in Human OKC}

The nAChR expression level and receptor affinity in cultured normal human OKC were characterized in radioligand binding assays using the nicotinic radioligand $\left[{ }^{3} \mathrm{H}\right] \mathrm{Nic}$. To determine the nonspecific binding, we used $100 \mu \mathrm{M}$ of the nonradiolabeled antagonist Mec. The saturable binding of $\left[{ }^{3} \mathrm{H}\right] \mathrm{Nic}$ was achieved (Fig. 1), demonstrating a high-affinity population of binding sites with a dissociation constant (Kd) of $40 \mathrm{~nm}$ and a maximal binding capacity (Bmax) of 23.3 $\mathrm{fmol} / \mathrm{mg}$ protein, or approximately $5800 \mathrm{nAChRs}$ per cell. Because preincubation of human bronchial epithelial cells with Nic alters expression of nAChRs in these cells (Zia et al, 1997), we hypothesized that exposure to Nic may also alter the function and the structure of nAChRs in OKC.

First, we tested this hypothesis using standard pharmacologic assays. As expected, pre-exposure of OKC to Nic, $10 \mu \mathrm{M}$, for 24 hours dramatically changed $\left[{ }^{3} \mathrm{H}\right] \mathrm{Nic}$ binding parameters (Table 1). The Bmax, characterizing the total number of nAChR binding sites, increased by almost two-fold and became equal to $42.9 \mathrm{fmol} / \mathrm{mg}$ protein, whereas the Kd value, charac-

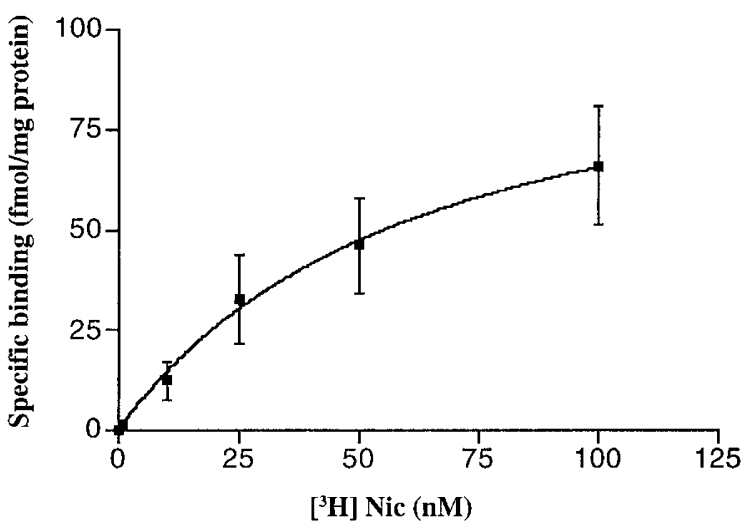

Figure 1.

Specific binding of $\left[{ }^{3} \mathrm{H}\right] \mathrm{Nic}$ to cultured human oral keratinocytes $(\mathrm{OKC})$. The saturable binding was achieved in the monolayers of OKC grown in the flat-bottomed, 24-well plates in keratinocyte growth medium (KGM), as described in "Materials and Methods." Each point represents a mean specific binding calculated in triplicate samples of $1 \times 10^{5} \mathrm{OKC} /$ well exposed to increasing concentrations of $(-)\left[{ }^{3} \mathrm{H}\right] \mathrm{Nic}$ for 4 hours at $4^{\circ} \mathrm{C}$ in the absence (total binding) or presence (nonspecific binding) of $100 \mu \mathrm{m}$ nonlabeled mecamylamine (Mec). The specific binding was obtained by subtracting the nonspecific binding from the total binding. 
Table 1. $\left[{ }^{3} \mathrm{H}\right]$ Nic Binding Parameters in Human OKC

\begin{tabular}{lccc}
\hline & & \multicolumn{2}{c}{ Bmax } \\
\cline { 3 - 4 } Treatment & Kd (nM) & fmol/mg protein & Binding sites/cell \\
\hline Nic & 62.3 & 42.89 & 10602 \\
Nic + Mec & 42.3 & 25.67 & 6345 \\
Control & 40.1 & 23.31 & 5762 \\
\hline
\end{tabular}

OKC, oral keratinocytes; Kd, dissociation constant; Bmax, maximal binding capacity; Nic, nicotine; Mec, mecamylamine.

terizing receptor ligand binding affinity, increased to $62.3 \mathrm{~nm}$. These changes could be blocked when the OKC were preincubated with $\mathrm{Nic}$ in the presence of 50 $\mu \mathrm{M} \mathrm{Mec}$, indicating that alterations of the pharmacologic parameters of $\left[{ }^{3} \mathrm{H}\right] \mathrm{Nic}$ binding to OKC resulted from the nAChR-coupled pathway that was constantly stimulated during preincubation of cells with Nic.

\section{Nic Up-Regulates nAChR Subunit Gene Expression in Human OKC}

In an attempt to determine the effects of Nic on the structural composition of the nAChR channels expressed on the cell membrane of OKC, we measured the expression of the genes coding for different nAChR subunits in OKC preincubated for 24 hours with $10 \mu \mathrm{M}$ Nic. Gene-specific primers for human $\alpha 3$, $\alpha 5, \alpha 7, \beta 2$, and $\beta 4$ subunits (Table 2) amplified products of the expected sizes (Fig. 2A). Nic exposure increased the mRNA levels of all subunits. In particular, the relative amounts of $\alpha 5$ and $\alpha 7$ mRNA increased 2.9- and 2.8-fold, respectively. These effects of Nic were almost completely blocked in the presence of $50 \mu \mathrm{M} \mathrm{Mec}$, indicating that regulation of the $\mathrm{nAChR}$ subunit gene expression is coupled to the nAChR-mediated intracellular signaling pathway. The glyceraldehyde-3-phosphate dehydrogenase (GAPDH) gene amplification remained constant in each experiment (Fig. 2A). The negative control experiments failed to produce any amplified products (not shown).

Treatment with Nic also up-regulated the synthesis of the nAChR subunit proteins, as judged from the results of Western blot experiments using previously characterized anti-nAChR subunit polyclonal antibodies (Fig. 2B). The relative ratios of protein expression increased for all $\mathrm{nAChR}$ subunits under investigation. Mec decreased only partially the amounts of the nAChR subunit proteins in Nic-treated cells. The levels of up-regulation of $\alpha 5$ and $\alpha 7$ on the translational levels, 2.4- and 2.1-fold, respectively, did not reach the level of up-regulation observed at the transcriptional level (Fig. 2A). Therefore, although the expression of these subunits increased in exposed OKC, the actual amount of each of the $\alpha 5$ - and $\alpha 7$-containing nAChRs among different nAChR types may be less than that in nonexposed cells.

The specificity of antibody binding to the immunoblotting membranes was confirmed by (a) the appearance of the subunit protein bands at the expected molecular weights (MW) (Nguyen et al, 2000a) and (b) the absence of these bands in negative control experiments omitting primary antibody or replacing it with an irrelevant, species- and isotype-matching antibody (not shown).

\section{AEST Stimulates nAChR Subunit Expression in OKC}

Having found that Nic can up-regulate the nAChR subunit gene expression in cultured human OKC, we hypothesized that tobacco products containing Nic may produce similar changes. To investigate this possibility, we measured the effects of AEST by the RT-PCR and immunoblotting assays. As expected, incubation of OKC for 24 hours in the presence of AEST containing $10 \mu \mathrm{m}$ of Nic induced up-regulation of the mRNA and the protein levels of nAChR subunits (Fig. 2, A and B). These changes could be abolished completely or partially in the presence of $50 \mu \mathrm{M}$ Mec. AEST up-regulated primarily the expression of the $\alpha 5$ subunit, as judged by the very

Table 2. The Human nAChR Subunit, Cell Cycle, and Cell Differentiation Genes Studied by Semiquantitative RT-PCR

\begin{tabular}{lcllr}
\hline \multicolumn{1}{c}{ Name } & Abbreviation & Gene Name & \multicolumn{1}{c}{ Accession No. } & \multicolumn{1}{c}{ Primers } \\
\hline $\begin{array}{l}\text { Glyceraldehyde-3 phosphate dehydrogenase } \\
\text { nAChR subunit }\end{array}$ & GADPH & GADP & J04038 & 214-234, 401-449 \\
$\alpha 3$ & $\alpha 3$ & CHRNA3 & M37981 & $375-394,840-863$ \\
$\alpha 5$ & $\alpha 5$ & CHRNA5 & M83712 & $433-456,868-892$ \\
$\alpha 7$ & $\alpha 7$ & CHRNA7 & U40583 & $367-388,814-835$ \\
$\beta 2$ & $\beta 2$ & CHRNB2 & U62437 & $1302-1326,1747-1770$ \\
$\beta 4$ & $\beta 4$ & CHRNB4 & U48861 & $1271-1296,1561-1584$ \\
p53-dependent G2 arrest & p53 & REPRIMO & AB04385 & $475-496,820-839$ \\
Cdk inhibitor p21 binding protein 1 & p21 & TOK-1 & AB040450 & $319-340,601-623$ \\
Proliferation-related Ki-67 antigen & Ki-67 & MK167 & X65550 & $299-321,727-750$ \\
Proliferation cell nuclear antigen & PCNA & PCNA & M15796 & $236-259,535-555$ \\
Cyclin D1 & Cyl 1 & CCND1 & M64349 & $279-301,568-589$ \\
Cytokeratin 1 & CK 1 & KRT1 & M98776 & $383-403,761-782$ \\
Cytokeratin 10 & CK 10 & KRT10 & J04029 & $374-397,782-803$ \\
Loricrin & & LOR & M61120 & $1007-1029,1181-1202$ \\
Filaggrin & & FLG & M24355 & $287-310,654-677$ \\
\hline
\end{tabular}

nAChR, nicotinic acetylcholine receptor. 
A
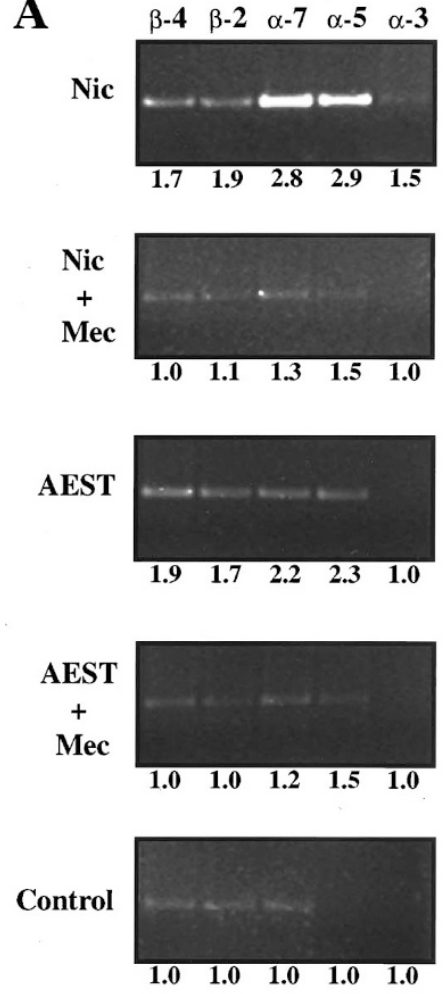

GAPDH
B

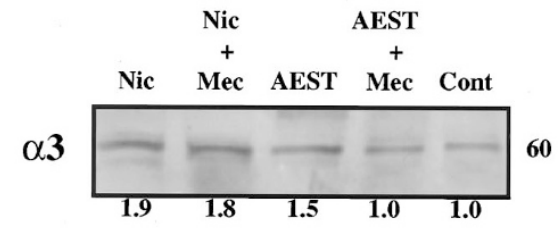

$\alpha 5$

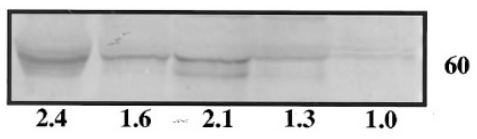

$\alpha 7$

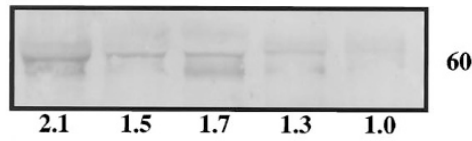

$\beta 2$

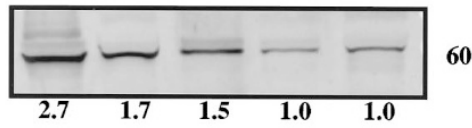

$\beta 4$

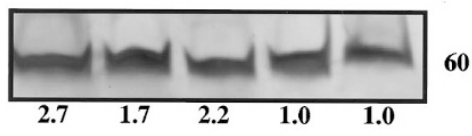

Figure 2.

Alterations of the nicotinic acetylcholine receptor (nAChR) subunit gene expression in human OKC exposed to pure nicotine (Nic) or aqueous extract of smokeless tobacco (AEST). Second-passage normal human OKC were treated with $10 \mu \mathrm{m}$ Nic or AEST containing $10 \mu \mathrm{m}$ Nic in the absence or presence of $50 \mu \mathrm{m}$ Mec for 24 hours, after which the total RNA and proteins were extracted and used in RT-PCR and immunoblotting assays. The mRNA and protein contents in the experimental (exposed) and control (nonexposed) cells were measured by standard densitometry of the specific bands in the gels, as described in "Materials and Methods." The ratio data are the means of the values obtained in at least three independent experiments. The images represent the typical appearance of the bands in gels. $A$, The relative $n A C h R$ subunit gene expression levels determined using subunit-specific RT-PCR primers (Table 2). Amplification yielded PCR products of the expected sizes: 489 bp for $\alpha 3,460$ bp for $\alpha 5,469$ bp for $\alpha 7,468$ bp for $\beta 2$, and 474 bp for $\beta 4$. Amplification of the glyceraldehyde-3-phosphate dehydrogenase (GAPDH) gene product (354 bp) was used to normalize the cDNA content in each sample and as a positive control for RT-PCR effectiveness. Both Nic and AEST increased the transcription of the nAChR subunit genes. The relative amounts of each up-regulated nAChR subunit increased by a range of 1.5- to 2.9-fold. The presence of Mec abolished these changes. B. The nAChR subunit proteins visualized in Western blots at the expected molecular weight (MW, shown in kilodaltons [kd] to the right of the gels) in the $15 \%$ SDS-PAGE-resolved keratinocyte proteins using subunit-specific antibodies, as described in "Materials and Methods." An increase of the relative amount of individual nAChR subunits in the presence of Nic or AEST ranged from 1.3- to 2.7-fold. The presence of Mec decreased most of these changes down to the control levels. The staining of the receptor bands was absent in the negative control experiments in which the membranes were treated without primary antibody or with irrelevant primary antibody of the same isotype and host, or the anti-peptide antisera before treatment of the blotting membrane were preincubated with the nAChR-specific peptide used for immunization (not shown).

similar degrees of the increase of its mRNA and protein levels, 2.3- and 2.1-fold, respectively. At the same time, the rate of increased $\alpha 7$ subunit protein synthesis, 1.7fold, did not reach the rate of up-regulated transcription of the $\alpha 7$ gene, 2.2-fold. Therefore, the net changes in the repertoire of the $\mathrm{nAChRs}$ expressed by treated cells depended on the changes in the gene coding of each of nAChR subunits.

\section{Effects of Nic and AEST on the Cell Cycle and Differentiation Markers in OKC}

Alterations in ACh signaling through keratinocyte $\mathrm{nAChRs}$ might bring changes in vital cell functions of the OKC controlled by this cytotransmitter. To test this hypothesis, we compared the effects of $10 \mu \mathrm{M}$ Nic and
AEST containing $10 \mu \mathrm{M}$ Nic on the expression of the cell cycle progression and the cell differentiation genes in cultured human OKC. This concentration of Nic has been used in the past to induce profound changes in the expression of keratinocyte differentiation markers (Grando et al, 1996). Gene-specific RTPCR primers were designed to amplify the human cell cycle marker genes coding for p53, p21, Ki-67, cyclin D1, and PCNA as well as the human keratinocyte differentiation marker genes coding for filaggrin, loricrin, CK 1, and CK 10 (Table 2). All primers yielded products of expected sizes. The OKC stimulated with either Nic or AEST showed increased levels of the $\mathrm{Ki}-67, \mathrm{PCNA}$, and p53 mRNA transcripts, as well as filaggrin and loricrin mRNA transcripts (Fig. 3A). The 
negative control experiments did not yield any PCR products (not shown).

By immunoblotting, we also found that the relative amounts of p53 and PCNA, as well as the amounts of p21 and cyclin D1, went up after the 24-hour exposures to Nic or AEST (Fig. 3B). Each protein band was visualized at the expected MW, namely, cyclin D1 at approximately $35 \mathrm{kd}$ (Bartek et al, 1993), PCNA at $37 \mathrm{kd}$ (Waseem and Lane, 1990), and p53 and p21 at 53 and $21 \mathrm{kd}$, respectively. The protein levels of $\mathrm{Ki}-67$, and the cell differentiation proteins filaggrin and loricrin did not differ from the control levels (not shown). These results indicated that the PCNA and p53 genes in treated cells were highly expressed at both the transcriptional and translational levels. The p21 and cyclin D1 were regulated predominantly at the translational level, and filaggrin and loricrin at the transcriptional level.

Mec blocked the changes induced by Nic and AEST (Fig. 3). These findings suggested that Nic contained in tobacco products can mediate some of the pathobiological effects of tobacco on oral mucosa of
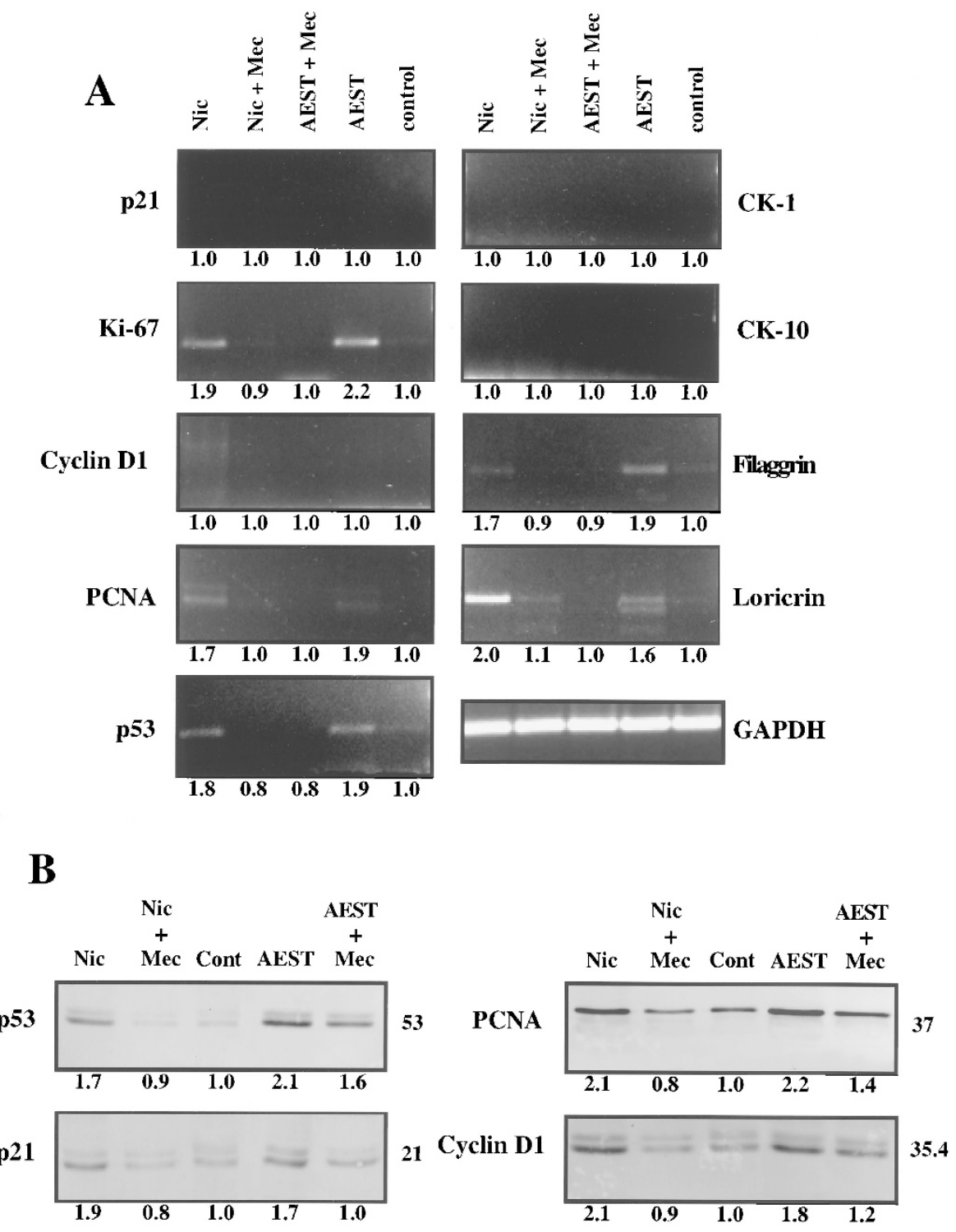

Figure 3.

Gene expression changes of the cell cycle and cell differentiation markers in OKC exposed to pure Nic or AEST. Total RNA and proteins were isolated from human OKC treated for 24 hours with $10 \mu \mathrm{m}$ Nic or AEST containing $10 \mu \mathrm{m}$ Nic in the absence or presence of $50 \mu \mathrm{m}$ Mec. The relative amounts of mRNA transcripts and protein levels of the cell cycle progression and cell differentiation markers were measured, and the results were expressed as described in the "Materials and Methods" section. The ratio data are the means of the values obtained in at least three independent experiments. The images represent the typical appearance of the bands in gels. A, The mRNA levels of the cell cycle genes coding for p21, Ki-67, cyclin D1, PCNA, and p53 and the cell differentiation genes coding for filaggrin, loricrin, CK 1 , and CK 10 were determined by RT-PCR using specific primers (Table 2) and CDNA from exposed versus nonexposed (control) OKC. A PCR product of the expected size was amplified by each primer set specific for p21 (305 bp), Ki-67 (452 bp), cyclin D1 (311 bp), PCNA (320 bp), p53 (365 bp), filaggrin (391 bp), loricrin (196 bp), CK 1 (400 bp), and CK 10 (430 bp). The levels of mRNAs coding for Ki-67, PCNA, p53, filaggrin, and loricrin were increased in the exposed, compared with the control OKC. B, The cell cycle proteins p53, p21, PCNA, and cyclin D1 were visualized in Western blots. The MW of each protein is shown in kd to the right of the gels. In both Nic- and AEST-treated cultures, the relative amounts of the studied cell cycle proteins increased the range from 1.7- to 2.2-fold, and Mec abolished most of these changes. The staining of these receptor proteins was absent in the negative control experiments described in the legend for Figure $2 \mathrm{~B}$ (not shown). 
smokeless tobacco users and that these effects may result from overstimulation of nAChRs in the stratified epithelium lining the mucocutaneous barrier.

\section{Structural Alterations of nAChRs in Rodents Exposed to Pure Nic or ETS}

To establish the relevance of the above in vitro findings to the pathobiologic effects of tobacco products in vivo, we studied the expression of the nAChR subunit genes in the oral tissue of rats and mice exposed for 3 weeks to aged and diluted sidestream cigarette smoke (ADSS), a surrogate for ETS, or drinking water containing equivalent concentration of Nic. In the RT-PCR assay, we used gene-specific primers matching both the rat and the mouse $\alpha 3, \alpha 5, \alpha 7, \beta 2$, and $\beta 4 \mathrm{nAChR}$ subunit gene sequences (Table 3). As expected, all nAChR primers that were used yielded products of expected sizes. In Western blots, we used the previously characterized anti-nAChR subunit antibodies raised against a mixture of oligopeptides representing the evolutionary conserved regions of each subunit protein (Nguyen et al, 2000a; Zia et al, 1997, 2000). The specificity of antibody binding to murine and rat OKC has been verified in IIF experiments (not shown).

Exposures to either ADSS or pure Nic in drinking water produced similar effects on the relative amounts of keratinocyte $\alpha 3, \alpha 5, \alpha 7, \beta 2$, and $\beta 4$ mRNA transcripts (Fig. 4A). Overall, an up-regulation of the synthesis of mRNAs coding for each of the five different nAChR subunits tested was similar in the two species and in the two exposure conditions. The level of receptor mRNA up-regulation ranged from 1.5- to 3.8-fold, with $\alpha 3$ and $\alpha 5$ being the most inducible genes. Notably, the relative amounts of mRNA of each nAChR subunit, except for $\beta 4$, in mice drinking Niccontaining water were always higher than those in rats. Also, an increase of transcription of nAChR genes was always higher in rodents exposed to pure Nic than in those exposed to ADSS.
The protein expression of $\alpha 3, \alpha 5, \alpha 7, \beta 2$, and $\beta 4$ subunits in rodents exposed to both Nic and ADSS was analyzed by immunoblotting (Fig. 4B). The increase in protein synthesis ranged from 1.2- to 2.4fold. In general, the protein synthesis ratios of nAChR subunit proteins across different experimental conditions increased to a lesser extent compared with the ratios of expression of the genes coding for these subunits (Fig. 4A). This finding indicates that the relative contribution of each of these subunits to formation of ACh-gated ion channels on the cell membrane of OKC may vary to a great extent, providing for the appearance of a unique nAChR repertoire in the oral epithelium of exposed rodents. Notably, the synthesis of $\alpha 3$ protein was actually down-regulated compared with that of other nAChR subunits under investigation.

The results of the IIF assay confirmed the above findings (Table 4). As expected from the results of the RT-PCR and immunoblotting assays, we found statistically significant $(p<0.05)$ increases of the relative amounts of keratinocyte $\alpha 3, \alpha 5, \alpha 7, \beta 2$, and $\beta 4$ nAChR subunits in the oral tissues of rats and mice exposed for 3 weeks to ADSS or drinking water containing an equivalent concentration of Nic, $10 \mu \mathrm{M}$, compared with the nonexposed controls. However, the rate of increase of each $\mathrm{nAChR}$ subunit differed substantially among different species and treatment conditions.

\section{Cell Cycle Alterations in Oral Tissue of Rodents Exposed to Nic or ADSS}

The oral tissues collected from rats and mice exposed for 3 weeks to Nic and ADSS were also used to determine the effects on the expression of cell cycle regulators, such as p53, p21, Ki-67, cyclin D1, and PCNA, and cell differentiation markers, such as CK 1 , filaggrin, and loricrin. The results of the RT-PCR and immunoblotting assays revealed that, although the expression of some genes was up-regulated, the

Table 3. The Rodent nAChR Subunit, Cell Cycle, and Cell Differentiation Genes Studied by Semiquantitative RT-PCR

\begin{tabular}{|c|c|c|c|c|}
\hline Name & Abbreviation & Gene Name & Accession No. & Primers \\
\hline $\begin{array}{l}\text { Glyceraldehyde- } 3 \text { phosphate dehydrogenase } \\
\text { nAChR subunit }\end{array}$ & GAPDH & Gapd & M17701 & $214-234, \quad 401-449$ \\
\hline$\alpha 3$ & $\alpha 3$ & Chrna3 & X03440 & $434-455, \quad 895-918$ \\
\hline$\alpha 5$ & $\alpha 5$ & Chrna5 & AF204689 & $788-801,1238-1257$ \\
\hline$\alpha 7$ & $\alpha 7$ & Chrna7 & AF225980 & $555-575,1027-1048$ \\
\hline$\beta 2$ & $\beta 2$ & Chrnb2 & AF09739 & $223-246, \quad 697-720$ \\
\hline$\beta 4$ & $\beta 4$ & Chrnb4 & U42976 & $720-742,1205-1227$ \\
\hline p53-dependent G2 arrest & p53 & Reprimo & AB043586 & $94-118, \quad 463-482$ \\
\hline Cdk inhibitor p21 binding protein 1 & p21 & Cdknla & AB017817 & $131-154, \quad 341-363$ \\
\hline Proliferation-related Ki-67 antigen & Ki-67 & Mki-67 & X82786 & $1091-1113,1570-1589$ \\
\hline Proliferation cell nuclear antigen & PCNA & Pcna & $\times 57800$ & $131-150, \quad 437-415$ \\
\hline Cyclin D1 & Cyl 1 & Cond1 1 & M64403 & $339-369, \quad 797-820$ \\
\hline Cytokeratin 1 & CK 1 & Krt1-1 & M27734 & $307-330, \quad 744-767$ \\
\hline Cytokeratin 10 & CK 10 & Krt1-10 & V00830 & $202-225, \quad 665-642$ \\
\hline Loricrin & & Lor & M34398 & $862-885,1104-1130$ \\
\hline Filaggrin & & $\mathrm{Flg}$ & $\mathrm{J} 03458$ & $278-298, \quad 588-609$ \\
\hline
\end{tabular}




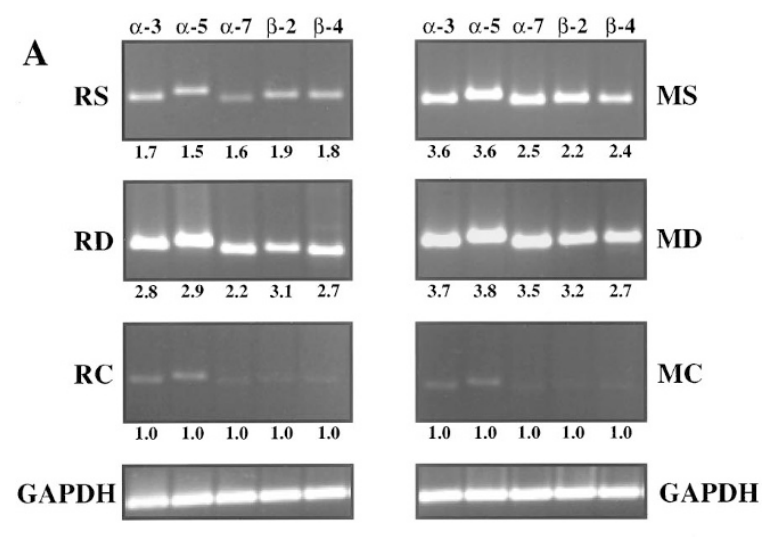

B

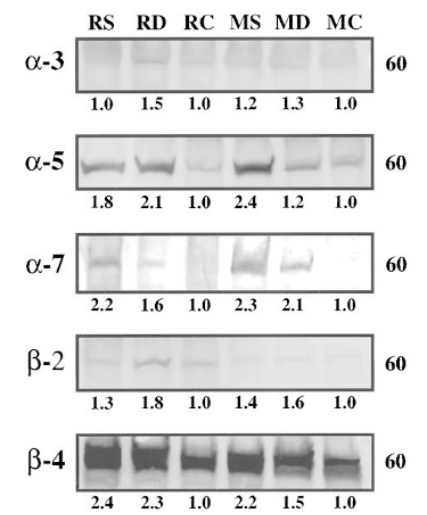

Figure 4.

Changes of the nAChR subunit gene expression in the oral tissue of rats and mice exposed to pure Nic or aged and diluted sidestream cigarette smoke (ADSS). Sprague-Dawley rats and Balb/c mice were exposed for 3 weeks to ADSS or an equivalent concentration of Nic in drinking water $(10 \mu \mathrm{M})$. The total RNA and proteins were extracted from oral tissues of rats exposed to ADSS (RS), rats exposed to Nic in drinking water (RD), mice exposed to ADSS (MS), and mice exposed to Nic in drinking water (MD) and nonexposed rodents of the same species, gender, weight, and age (control rats and mice: $\mathrm{RC}$ and $\mathrm{MC}$, respectively). The ratio data are the means of the values obtained in at least three independent experiments. The images represent the typical appearance of the bands in gels. A, Detection of the nAChR transcripts by RT-PCR using primer sets specific for rodent $\alpha 3, \alpha 5, \alpha 7, \beta 2$, and $\beta 4$ nAChR subunit transcripts (Table 3) yielded PCR products of the expected sizes: 485 bp for $\alpha 3,480$ bp for $\alpha 5,494$ bp for $\alpha 7,477$ bp for $\beta 2$, and 482 bp for $\beta 4$. Similar changes for all receptor subunits were observed in the groups of animals exposed to tobacco smoke and Nic-containing drinking water. The mRNA ratio levels in exposed animals exceeded the control levels in a range from 1.5- to 3.8-fold. B, In all groups of exposed animals, an increase in the nAChR subunit expression was also detectable at the protein level, ranging from 1.2- to 2.4 -fold. The immunoblotting assay was performed exactly as described in the legend for Figure $2 \mathrm{~B}$, using all appropriate negative controls.

expression of other genes was down-regulated. We found that the amount of mRNA coding for cyclin D1 and PCNA was increased in rats and mice under all experimental conditions, whereas that coding for $\mathrm{p} 21$, p53, and Ki-67 was decreased only in rats and remained unchanged in the majority of exposed mice (Fig. 5A). The ratios of the CK 1 gene expression were increased in all exposed animals.

The majority of animals in the exposed groups showed a decrease in the protein expression of p21 and $\mathrm{p53}$, but the latter was increased in mice exposed to ADSS (Fig. 5B). We also found that the protein synthesis of cyclin D1 and PCNA was down-regulated (Fig. 5B). The protein levels of CK 1, filaggrin, and loricrin did not show appreciable changes (data not shown). Taken together, these findings indicate that, although the net effect of the animal exposure to Nic and ADSS results in decreased amounts of the cell cycle regulatory molecules in OKC, the level at which the down-regulation occurs, ie, transcriptional or translational, is different for each particular molecule.

\section{Accelerated Squamatization of the Oral Epithelium in Exposed Rodents}

Having detected the above abnormalities of the alterations in the structure and function of nAChRs and in the cellular regulatory process in rodents exposed to pure Nic or ADSS, we sought to determine the potential implication of the revealed anomalies to the fate of OKC in the stratified epithelium. Toward this goal, we evaluated the transcriptional and translational levels of a well-characterized and highly sensitive and specific marker of squamatization of the stratified squamous epithelium, CK 10, in rats and mice exposed to ADSS or Nic in drinking water. We knew that Nic fosters terminal differentiation of cultured epidermal and oral epithelial cells (Grando et al, 1996; Kwon et al, 1999; Theilig et al, 1994) and anticipated similar effects in vivo. As expected, the amount of CK 10 in the oral epithelium increased several times in each group of exposed animals. We found an increase in the CK 10 mRNA transcripts that ranged from 1.4- to 3.1-fold (Fig. 6A). In addition, we observed a 1.5- to 2.2-fold increase in the CK 10 protein level detectable by using Western blot (Fig. 6B). The up-regulated expression of CK 10 was also confirmed in a series of IIF experiments, which revealed a 1.6- to 3.6-fold increase of the relative intensity of the specific staining for CK 10 in the oral tissues of exposed rats and mice (Fig. 6C). These results suggested that the nAChR-mediated coordinated changes in cell cycle regulation, which lead to excessive and possibly premature squamatization, is a common mode of pathobiologic action of Nic-containing products on the stratified squamous epithelium.

\section{Discussion}

In this study, we demonstrate for the first time that chronic stimulation of OKC with Nic alters the genetically determined program of the cell differentiationdependent expression of nAChR subunits. This process is associated with changes in the expression of the cell cycle genes that can alter the dynamic equilibrium between cell growth and maturation toward an early and excessive squamatization of OKC.

The nAChRs are classic representatives of a large superfamily of ligand-gated ion channel proteins, or ionotropic receptors, which mediate the influx of $\mathrm{Na}^{+}$ and $\mathrm{Ca}^{2+}$ and the efflux of $\mathrm{K}^{+}$(Steinbach, 1990). The $n A C h R s$ in the gingival and esophageal epithelia have been mapped in the past by IIF using subunit-specific antibodies (Nguyen et al, 2000a). The diversity of 
Table 4. Relative Amounts of Different nAChR Subunits Expressed by OKC in Mice and Rats Exposed to Pure Nic or ADSS versus Controls (mean $\pm S D, n=9)^{a}$

\begin{tabular}{|c|c|c|c|c|c|c|}
\hline \multirow[b]{2}{*}{ nAChR Subunit } & \multicolumn{3}{|c|}{ Mice } & \multicolumn{3}{|c|}{ Rats } \\
\hline & ADSS & Nic & Control & ADSS & $\mathrm{Nic}$ & Control \\
\hline${ }^{\alpha 3} p^{b}$ & $\begin{array}{c}100.9 \pm 20.1 \\
0.03\end{array}$ & $\begin{array}{c}106.1 \pm 10.7 \\
0.01\end{array}$ & $49.0 \pm 17.64$ & $\begin{array}{c}151.8 \pm 20.9 \\
<0.01\end{array}$ & $\begin{array}{c}151.5 \pm 8.8 \\
<0.01\end{array}$ & $50.9 \pm 4.5$ \\
\hline$\alpha 5$ & $208.1 \pm 2.9$ & $145.6 \pm 9.7$ & $63.3 \pm 9.7$ & $168.4 \pm 9.1$ & $132.8 \pm 8.9$ & $53.3 \pm 5.4$ \\
\hline$\alpha 7^{p}$ & $\begin{array}{c}<0.01 \\
43.2 \pm 12.3\end{array}$ & $\begin{array}{c}<0.01 \\
61.5 \pm 13.5\end{array}$ & $14.3 \pm 2.5$ & $\begin{array}{c}<0.01 \\
60.2 \pm 9.6\end{array}$ & $\begin{array}{c}<0.01 \\
62.0 \pm 5.8\end{array}$ & $33.9 \pm 4.9$ \\
\hline$p$ & $<0.01$ & $<0.01$ & & 0.01 & 0.03 & \\
\hline $\begin{array}{r}\beta 2 \\
p\end{array}$ & $\begin{array}{c}150.3 \pm 33.0 \\
0.01\end{array}$ & $\begin{array}{c}117.1 \pm 11.9 \\
<0.01\end{array}$ & $60.4 \pm 4.1$ & $\begin{array}{c}172.0 \pm 7.9 \\
0.01\end{array}$ & $\begin{array}{c}168.8 \pm 12.6 \\
0.01\end{array}$ & $85.8 \pm 27.5$ \\
\hline $\begin{array}{r}\beta 4 \\
p\end{array}$ & $\begin{array}{l}172.6 \pm 14.1 \\
\quad<0.01\end{array}$ & $\begin{array}{c}179.8 \pm 2.86 \\
0.01\end{array}$ & $52.5 \pm 0.8$ & $\begin{array}{l}177.1 \pm 12.2 \\
\quad<0.01\end{array}$ & $\begin{array}{c}172.1 \pm 9.8 \\
<0.01\end{array}$ & $78.2 \pm 18.6$ \\
\hline
\end{tabular}

ADSS, aged and diluted sidestream cigarette smoke; IIF, indirect immunofluorescence.

${ }^{a}$ The cryostat sections of the oral tissue obtained from euthanized rats and mice exposed for 3 weeks to pure Nic in drinking water (10 $\left.\mu \mathrm{M}\right)$ or ADSS containing equivalent dose of Nic, or control, nonexposed rodents of the same species, gender, weight, and age were stained with rabbit anti-nAChR subunit antibodies (Table 5), and the relative amounts of the subunit proteins in OKC were computed using the semiquantitative IIF assays, as detailed in "Materials and Methods."

${ }^{b}$ Statistical significance of differences compared to the control levels determined in the tissue samples from nonexposed animals of the same species.

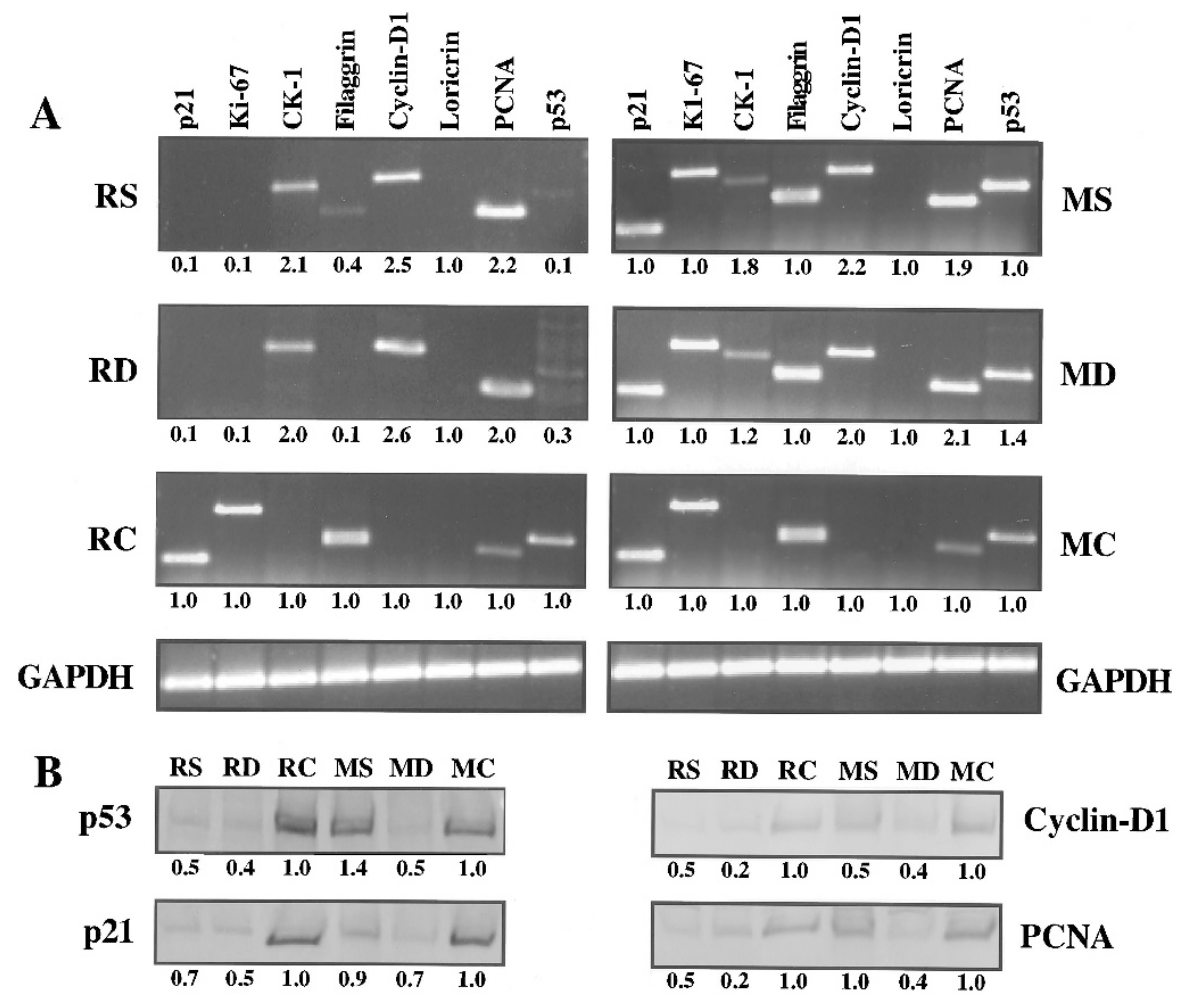

Figure 5.

Gene expression changes of the cell cycle and differentiation markers in the oral tissue of rats and mice exposed to pure Nic or ADSS. Cell cycle and differentiation gene expression alterations were analyzed by isolating the total RNA and protein from oral tissues of exposed animals, as detailed in "Materials and Methods." The ratio data are the means of the values obtained in at least three independent experiments. The images represent the typical appearance of the bands in gels. A, The cell cycle and differentiation gene expression in the oral tissue of rats exposed to ADSS (RS), rats exposed to Nic in drinking water (RD), mice exposed to ADSS (MS), mice exposed to Nic in drinking water (MD), and control, nonexposed rats (RC) and mice (MC) of the same species, gender, weight, and age was studied by RT-PCR employing rodent gene-specific pairs of primers shown in Table 3. Each primer set yielded a PCR product of the expected size: 233 bp for p21, 499 bp for Ki-67, $482 \mathrm{bp}$ for cyclin D1, $307 \mathrm{bp}$ for PCNA, and $389 \mathrm{bp}$ for p53. Although the expression of some cell cycle and differentiation genes was down-regulated, that of the others was up-regulated in the majority of exposed animals. B, Changes in the protein levels of the cell cycle markers were also detectable by immunoblotting. In the majority of the exposed animals, the synthesis of p21, p53, cyclin D1, and PCNA proteins was decreased.

$\mathrm{nAChR}$ channels expressed by OKC in the course of their development in the epithelium can allow ACh to act differently throughout the stages of keratinocyte differentiation. Nic can substitute for ACh at nAChRs and thus influence autocrine and paracrine regulation of the OKC through the cholinergic pathway. We have shown that Nic accelerates maturation of epidermal keratinocytes and that mature keratinocytes express 
A

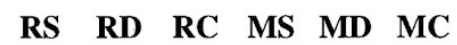

\section{CK-10}

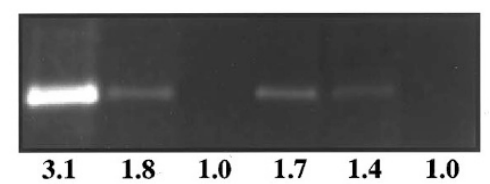

GAPDH

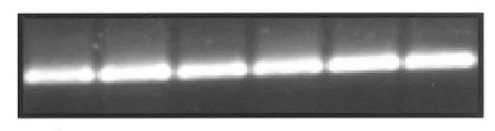

B

CK-10

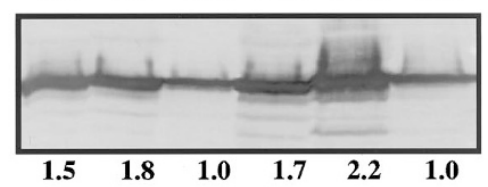

C

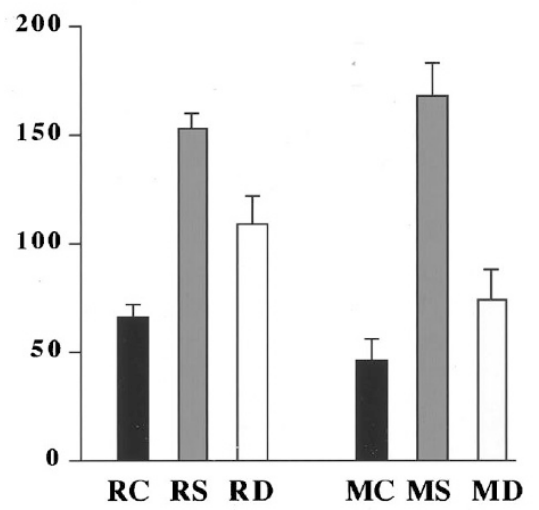

Figure 6.

Abnormal squamatization of OKC residing in the oral tissue of rats and mice exposed to pure Nic or ADSS. The specimens of oral tissues were also used for RT-PCR, immunoblotting, and indirect immunofluorescence (IIF) analysis of the expression of CK 10 in OKC of rats exposed to ADSS (RS), rats exposed to Nic in drinking water (RD), mice exposed to ADSS (MS), mice exposed to Nic in drinking water (MD), and nonexposed rats (RC) and mice (MC) of the same gender, weight, and age. The data represent typical results obtained in a series of at least three independent experiments. A, The primer set matching the rodent sequence of the CK 10 gene (Table 3) yielded a PCR product of the expected size, $461 \mathrm{bp}$. In all groups of exposed animals, the relative amounts of the CK 10 mRNA transcript were abundant and exceeded the control levels in a range from 1.4- to 3.1-fold. B, In all exposed groups, an increase of CK 10 expression was also detectable by immunoblotting. At the protein level, an increased expression of CK 10 ranged from 1.5- to 2.2-fold. C, Semiquantitative IIF analysis of relative amounts of CK 10 in OKC residing in the oral mucosa of different rodent exposure groups revealed a significantly increased expression, compared to nonexposed controls $(p<0.05)$. No specific staining could be seen in cryostat sections of rodent oral tissue in negative control experiments in which the primary antibody was either omitted or replaced with an irrelevant, isotype-matching antibody.

an increased number of nAChRs (Grando et al, 1995, 1996). The composition of nAChRs in the respiratory epithelium of chronic smokers is significantly different from that of nonsmokers, and these in vivo changes can be reproduced in cultures of bronchial epithelial cells exposed to $10 \mu \mathrm{M} \mathrm{Nic} \mathrm{(Zia} \mathrm{et} \mathrm{al,} \mathrm{1997).} \mathrm{Taken}$ together, these findings led us to hypothesize that similar changes might also occur in OKC exposed to Nic, ETS, or AEST.
In this study, we demonstrate that preincubation of OKC with Nic increases the number of nAChRs in these cells. An increase of Bmax, depicting an increase in the total number of Nic binding sites, showed that pretreatment of OKC with Nic increases the number of nAChRs on the cell membrane from approximately 5800 to approximately 10600 . To identify the Nic-induced structural changes of keratinocyte nAChRs, we exposed normal human OKC to pure Nic or whole AEST containing the same concentration of $\mathrm{Nic}$ and in both cases found dramatic changes in the subunit composition. We observed increases in the mRNA and/or protein levels of the subunits that form the ACh-gated ion channels that are permeable to $\mathrm{Ca}^{2+}$ (Delbono et al, 1997; Fieber and Adams, 1991; Grando et al, 1996; Quik et al, 1997). A switch in the nAChR subunit composition from predominantly $\alpha 3 \beta 2$ and $\alpha 3 \beta 4$ channels to $\alpha 3 \beta 2 \alpha 5$ and $\alpha 3 \beta 4 \alpha 5$ channels increases $\mathrm{Ca}^{2+}$ influx (Gerzanich et al, 1998), which may launch the keratinocyte differentiation program (Grando et al, 1996). Activation of $\alpha 7$-made nAChRs can lead to both a transmembrane $\mathrm{Ca}^{2+}$ influx and a release of $\mathrm{Ca}^{2+}$ from intracellular stores (Quik et al, 1997). The changes observed by us in Nic-treated OKC could be abolished in the presence of the specific nicotinic antagonist $\mathrm{Mec}$, indicating that they were mediated by the intracellular pathways coupled by keratinocyte nAChRs. Thus, the primary target for Nic toxicity in OKC appeared to be the nAChRs themselves, as illustrated by the changes in their number, structure, and function.

A switch in the subunit composition of an AChgated ion channel could bring about a corresponding switch in the ionic properties of the channel, leading to an array of molecular and metabolic events in the OKC. The nicotinic effects of ACh are associated with stimulation of DNA synthesis (Tominaga et al, 1992; Villablanca, 1998). The crucial role of ion channels, such as nAChRs, in maintenance of cell viability has been demonstrated previously (Mulle et al, 1992). Overstimulation of $n A C h R s$ with agonists has been shown to modify ACh metabolism, secretion, and signaling, through both the nicotinic and the muscarinic pathways, with toxicological implications (Ogle and Glavin, 1996; Sastry, 1995; Toth et al, 1993; Wang, 1997). Altered cell proliferation, a direct effect of Nic, was seen in cultures of renal epithelial cells (Horster et al, 1984), and a concentration-dependent wave of cell proliferation was observed in rat tracheal epithelium after acute exposure to tobacco smoke (Wells and Lamerton, 1975). The homomeric $\alpha 7$ nAChR channel has been implicated in the activation of a signaling pathway facilitating apoptosis (Hory-Lee and Frank, 1995; Orr-Urtreger et al, 2000). The substantial, yet restricted, influx of $\mathrm{Ca}^{2+}$ through the homomeric nAChR channel made by the $\alpha 7$ subunits might direct the cell cycle progression via a "squamatization" pathway, which could allow the cell to avoid apoptosis.

We compared the effects of the in vitro exposure of human OKC to AEST and pure Nic with the in vivo effects of ADSS and pure Nic exposures. In the ADSS 
exposure experiments, we employed an established system that distributes smoke to each animal (Teague et al, 1994). To induce changes characteristic of chronic tobacco usage, the animals received treatment for 3 weeks (Booyse et al, 1981; Pittilo et al, 1990; Zimmerman and McGeachie, 1987). The dosing of Nic was chosen to correlate well with the levels found in the blood and mucous secretions of smokers and snuffers. On smoking days, Nic concentrations in human plasma range between 4 and $72 \mathrm{ng} / \mathrm{mL}$ (Peacock et al, 1993) and are extremely high in saliva (>1300 ng/mL) (Lindell et al, 1993; Russell et al, 1980). The peak Nic plasma levels in the snuffers is similar to the peak values in heavy smokers (Russell et al, 1980, 1981). Past experiments in our laboratory using conditions identical to ADSS have found plasma Nic levels in rats to range from 2 to $17 \mathrm{ng} / \mathrm{mL}$, with an average concentration of $12 \mathrm{ng} / \mathrm{mL}$ (Joad et al, 1993, 1995). Therefore, the conditions of the ADSS exposure generated experimentally for rodents are highly relevant to conditions seen in humans.

In addition to changes in the $\mathrm{nAChR}$ expression, both in vitro and in vivo exposures to pure Nic and tobacco products altered the expression of the cell cycle and cell differentiation genes that are connected to keratinocyte growth and maturation. We detected abnormalities in the expression of the following genes: (a) Ki-67, a nuclear protein expressed during the G1, S, G2, and M phases (MacCallum and Hall, 1999); (b) PCNA, a protein that is expressed mostly at the G1-S phase (Tsurimoto, 1999); (c) cyclin D1, a cyclin protein implicated in the induction and control of mitosis (Hunter and Pines, 1994); (d) p21 waf-1, a cyclindependent kinase inhibitor (El-Deiry et al, 1993) that plays an important role during cell differentiation (Poluha et al, 1997); and (e) p53, a regulatory protein that affects the cell cycle arrest (Lane and Benchimol, 1990). p53 is believed to control cell cycle progression via activation of the bax gene, which causes the cell to undergo apoptosis (Miyashita and Reed, 1995). p53 also regulates cyclin-dependent kinase inhibitors such as $\mathrm{p} 21$, which blocks the phosphorylation of $\mathrm{pRb}$ by cyclin D1-dependent kinases and forms complexes with PCNA to inhibit DNA synthesis (Hunter and Pines, 1994). In addition, p21 may block apoptosis during cell terminal differentiation (Walsh, 1997).

The short-term Nic exposure increased all of the studied cell cycle parameters in OKC, in keeping with the notion that overexpression of p53 and/or Ki-67 is present in oral epithelium of tobacco users (van Oijen et al, 1998, 1999) and in snuff-induced lesions (Wedenberg et al, 1996). However, the long-term exposure resulted in a consistent decrease of the p53 and p21 mRNA and protein levels and a decrease of the mRNA level of Ki-67. Through immunoblotting assays we also found a decreased protein synthesis of PCNA and cyclin D1, despite abundant mRNA levels of these cell cycle regulatory proteins. This indicates that the expression of the genes coding for p21 and p53 was down-regulated at the transcriptional level, whereas that of PCNA and cyclin D1 was down-regulated at the translational level. The differences in relative changes of the mRNA and protein levels of the same molecule may be also attributed to known differences in their half lives or stability (Sonenberg et al, 2000). Because the effects of pure Nic in both in vitro and in vivo experiments matched those of AEST and ADSS, respectively, and because all could be blocked with $\mathrm{Mec}$, we believe that observed changes in OKC resulted from the nAChR-mediated pathway, rather than from the pathways affected by other chemicals present in AEST and ADSS, which was used as a surrogate for ETS.

Acute and chronic exposures to an agonist were expected to produce opposite effects on the keratinocyte functions controlled by ACh. We have shown in the past that short-term exposure to Nic or cholinergic (nicotinic) agonists augments cytoplasm motility and lateral migration of individual cells and strengthens cell-to-cell and cell-to-substrate attachments in keratinocyte monolayers (Grando et al, 1993, 1995). Longterm exposures, on the other hand, produce the opposite effect, which is manifested by cell shrinkage and detachment (Zia et al, 1997) as well as by inhibition of lateral migration (Zia et al, 2000). As expected from previous results, in this study most short-term effects of Nic, observed after 24 hours of in vitro exposure, differed from long-term effects of Nic, observed after 3 weeks of in vivo exposure. The changes in the cell cycle gene expression observed in rodents after a 3-week exposure fit neither with the "growth promotion" pattern, manifested by the up-regulation of Ki-67 and PCNA and/or down-regulation of p53, nor with the "growth-arrest" pattern, characterized by a decrease or disappearance of Ki-67 and PCNA and/or up-regulation of p53 and p21. We, therefore, propose that the cell cycle progression in the stratified epithelium of exposed animals proceeds via a unique path that is deleterious to the OKC because it can lead to various abnormalities, including tumorigenesis.

Oral cancer is the sixth most-common cancer in the world, accounting for approximately $4 \%$ of all cancers and $2 \%$ of all cancer deaths (Boring et al, 1994). Until recently, studies of oncogenesis have been focused on the regulation of cell proliferation. It has recently become increasingly clear that defective negative growth control, including growth arrest and apoptosis, contributes significantly to the origin and progression of cancer (Ellis et al, 1991; Liebermann et al, 1995). Frequent users of smokeless tobacco have an increased risk for developing gingival recession, periodontal disease, and oral cancer (Johnson and Squier, 1993; Sugar et al, 1996; Weintraub and Burt, 1987). The strongest link is with cancers of the cheek and gum. Other associations have been suggested for cancers of the nasal cavities, esophagus, larynx, and pancreas (Brinton et al, 1984; Connolly et al, 1986). Most commonly, however, the use of smokeless tobacco results in a white patch on the oral mucosa that does not rub off or bleed and is described as (hyper) keratosis or leukoplakia. Oral snuff causes alterations in the affected epithelium that are characteristic of the cornified epithelium and manifested by the expression of the squamatization markers, CKs 1, 9, 10, and 11 
(Luomanen et al, 1997). Four types of epithelial change are observed in the tobacco-associated oral mucosal lesions: hyperkeratosis, orthokeratosis, pale surface staining, and basal cell hyperplasia. The thickness of hyperkeratosis correlates directly with the amount of tobacco use, and the use of snuff is more frequently associated with development of oral mucosal lesions compared with chewing tobacco (Daniels et al, 1992). These tobacco-related lesions may become dysplastic (Andersson et al, 1989; Hirsch et al, 1982; Kaugars et al, 1989) and even undergo a malignant transformation (Sundstrom et al, 1982).

In this study, chronic stimulation of the nicotinic pathways of ACh signaling in the oral epithelium of the exposed rodents resulted in premature squamatization of OKC, manifested by rapid acquisition of abundant amounts of the CK 1 and CK 10 squamatization markers. We have reported previously that long-term incubation with Nic markedly increases the number of epidermal keratinocytes forming cornified envelopes and staining with antibodies to the cell differentiation markers CKs 10 and 11, filaggrin, involucrin, and transglutaminase type I, and that Mec can prevent this enhanced expression (Grando et al, 1996). Similar differentiating effects of Nic have been observed in the keratinocytes that make up the oral mucosa (Kwon et al, 1999). Thus, these finding increase our understanding of the mechanism for epithelial hyperplasia and squamous cell differentiation in tobacco users.

In conclusion, tobacco is the most important cause of avoidable human deaths. However, the mechanisms contributing to the illnesses that cause these deaths are still not completely elucidated. Cumulative results revealed the negative effects of $\mathrm{Nic}$ on cell functioning in various nonneuronal locations, some of which may provide a mechanism for the development of tobacco-related illnesses. The newly discovered epithelial nAChRs in human gingival and esophageal epithelium may contribute to the development of tobacco-associated morbidity. The pathobiological mechanisms of aberrant cell cycle progression leading to mucosal lesions in chronic tobacco users may involve Nic-induced alterations of the keratinocyte ACh axis. Our findings of the biological effects of Nic, ETS (ADSS), and AEST on the cell cycle and differentiation markers of OKC help elucidate the mechanisms by which tobacco products produce deleterious effects in the upper digestive tract. Although the binding of $\mathrm{Nic}$ to its receptors on the cell membrane of OKC potentiality leads to activation of multiple signal transduction pathways, changes in the concentration of intracellular $\mathrm{Ca}^{2+}$ may account for the negative effect of $\mathrm{Nic}$ on the normal unfolding of the genetically determined program of the cell cycle progression. By interfering with $\mathrm{ACh}$ signaling in $\mathrm{OKC}$, Nic can alter the normal balance of cell growth and differentiation, which accelerates squamatization and increases the risk for malignant transformation. These results provide a scientific basis for new approaches to clinical solutions that could ameliorate the consequences of tobacco use and intercede in disease pathways. Learning the pharmacology of Nic toxicity in nonneu- ronal locations will help in the development of an effective prevention program wherein the hazardous effects of Nic can be anticipated and prevented using a pharmacological antagonist of nAChRs. Collectively, these results will contribute to a better understanding of the biochemical pathways mediating the deleterious effects of tobacco products on nonneuronal tissues.

\section{Materials and Methods}

\section{Cell and Tissue Source}

Normal human OKC were obtained from attached gingiva. (This study has been approved by the University of California Davis Human Subjects Review Committee.) Attached gingival samples destined for primary cell culture were freed of clotted blood and rinsed in $\mathrm{Ca}^{2+}$ - and $\mathrm{Mg}^{2+}$-free phosphate-buffered saline (PBS; Gibco BRL, Gaithersburg, Maryland). Samples were then cut into 3- to 4-mm pieces, placed epithelium up into a sterile cell culture dish containing $2.5 \mathrm{~mL}$ of $0.125 \%$ trypsin (Sigma Chemical Company, St. Louis, Missouri) and $2.5 \mathrm{~mL}$ of minimum essential medium (Gibco BRL) supplemented with $50 \mu \mathrm{g} / \mathrm{mL}$ gentamicin, $50 \mu \mathrm{g} / \mathrm{mL}$ kanamycin sulfate, $10 \mathrm{U} / \mathrm{mL}$ penicillin G, $10 \mu \mathrm{g} / \mathrm{mL}$ streptomycin, and $5 \mu \mathrm{g} / \mathrm{mL}$ amphotericin (all from Gibco BRL). Tissue was incubated overnight at $37^{\circ} \mathrm{C}$ in a humidified atmosphere with $5 \% \mathrm{CO}_{2}$. The epithelial sheets were then separated from the lamina propria in minimum essential medium containing $20 \%$ heat-inactivated newborn calf serum (Gibco BRL), and individual OKC were isolated by gentle pipetting followed by centrifugation, as detailed elsewhere (Nguyen et al, 2000a). The OKC were grown at $37^{\circ} \mathrm{C}$ and $5 \% \mathrm{CO}_{2}$ in $25 \mathrm{~cm}^{2}$ or $75 \mathrm{~cm}^{2}$ Falcon culture flasks (Corning Glass Works, Corning, New York) in serum-free keratinocyte growth medium (KGM, Gibco BRL) containing $0.09 \mathrm{~mm} \mathrm{Ca}{ }^{2+}$. Cell culture medium was changed every 3 days, and cultures were passaged at approximately $80 \%$ confluence.

\section{Cell Culture Exposure Experiments}

Second-passage normal human OKC were exposed to $10 \mu \mathrm{M}$ of pure Nic or AEST containing the same concentration of Nic in the absence or presence of 50 $\mu \mathrm{M}$ of the specific nicotinic antagonist Mec for 24 hours at $37^{\circ} \mathrm{C}$ and $5 \% \mathrm{CO}_{2}$. Both Nic and Mec were purchased from Sigma Chemical Company and dissolved in KGM. Control OKC were incubated in KGM without any additions. The AEST was extracted from standardized smokeless tobacco (1S3 moist snuff; University of Kentucky, Lexington, Kentucky) using a standard procedure (Oh et al, 1990). Briefly, smokeless tobacco was mixed with five volumes $(5 \mathrm{~mL} / \mathrm{g})$ of $0.1 \mathrm{M}$ phosphate buffer, $\mathrm{pH} 7.0$, and stirred at room temperature for 24 hours. The $\mathrm{pH}$ of the extract was adjusted to 7.0, and the extract was centrifuged at $40,000 \times g$ for 1 hour. The supernatant was filtered through a Millipore filter (pore size $0.45 \mu \mathrm{m}$ ), lyophilized, and stored at $-80^{\circ} \mathrm{C}$. On the day of experiment, 
the AEST was mixed with KGM to a concentration of $10 \mu \mathrm{M}$ Nic per aliquot to match the concentration of pure Nic used in parallel experiments. The experiments were done in triplicate for both exposed and control, nonexposed cultures, and the cells from each culture were harvested and used in experiments separately. In each individual culture, $2.5 \times 10^{6}$ viable cells were used to extract total RNA and proteins.

\section{Animal Exposure Experiments}

Male, specific pathogen-free Sprague-Dawley rats (300-325 g body weigh) were obtained from ZivicMiller Laboratories (Zelienople, Pennsylvania). Male Balb/c mice (30-35 g body weight) were obtained from Jackson Laboratories (Bar Harbor, Maine). Rats were housed two per cage and mice four per cage. They were allowed free access to food and water. The cages were maintained at $21^{\circ} \mathrm{C}$ with lighting for 12 hours daily. After one week of acclimatization, the animals were exposed to ETS (see below) or to an equivalent concentration of $\mathrm{Nic}$ in drinking water for 3 weeks. This study was approved by University of California Davis Committee on the Use of Animals in Research. We employed a sidestream smoke exposure system that provides for whole-body exposure (Teague et al, 1994). Briefly, a TE-10 smoking machine (Teague Enterprises, Davis, California) burned 1RF4 reference cigarettes (Tobacco and Health Research Institute, University of Kentucky) that had been temperature- and humidity-conditioned to generate ADSS as a surrogate to ETS. Each 1RF4 cigarette delivers approximately $0.8 \mathrm{mg}$ of $\mathrm{Nic}$ (Teague et al, 1994). Each cigarette was smoked under rigid conditions of 1 puff ( $35 \mathrm{~mL}$ volume for 2 seconds duration)/ minute over a period of 8 minutes. A portion of the air and smoke from the conditioning chamber was further mixed with fresh filtered air before introducing the cigarette smoke into the $0.44 \mathrm{~m}^{3}$ animal exposure chambers. Daily measurements of total suspended particulates of $\mathrm{Nic}$ and carbon monoxide were performed. Mean concentrations over the course of the study were $1 \pm 0.07 \mathrm{mg} / \mathrm{m}^{3}$ of total suspended particulates, $344 \pm 85 \mu \mathrm{g} / \mathrm{m}^{3}$ of $\mathrm{Nic}$, and $4.9 \pm 0.7$ parts/million of carbon monoxide. This concentration of sidestream cigarette smoke was selected because it represents a high ambient level that individuals could encounter at home or in other settings where smoking occurs (Ji et al, 1998). In another series of exposure experiments, rats and mice drank water containing $10 \mu \mathrm{M}$ of pure Nic. The nonexposed control rats and mice were housed in a chamber and received pure water and filtered clean air only. At the end of the experiments, the animals were anesthetized with 1 $\mathrm{mg} / \mathrm{kg}$ body weight of pentobarbital sodium. The animals were euthanized, and oral tissue samples were collected. The oral tissue was either fresh-frozen in liquid nitrogen for RNA and protein extractions or freshly embedded in O.C.T. Tissue Tek compound (Sakura, Tokyo, Japan) for use in IIF experiments.

\section{RT-PCR Assay}

Total RNA was extracted from cultured human OKC, and gingival and esophageal tissues were removed from both exposed and control rats and mice using the guanidinium thiocyanate phenol chloroform extraction procedure (TRIzol Reagent, Gibco BRL), as described elsewhere (Chomczynski and Sacchi, 1987). The quantity and structural integrity of RNA samples were confirmed by electrophoresis on $1.1 \%$ agarose/2.2 $\mathrm{M}$ formaldehyde gels and by optical density of the $260 / 280 \mathrm{~nm}$ ratio. Only samples that showed intact $28 \mathrm{~S}$ and $18 \mathrm{~S}$ ribosomal RNA bands and exhibited a 260/280 $\mathrm{nm}$ ratio $>1.8$ were used in the experiments. One microgram of dried, DNase-treated RNA was reverse-transcribed in $20 \mu \mathrm{L}$ of RT-PCR mix (50 mM Tris, [pH 8.3], $6 \mathrm{~mm} \mathrm{MgCl}_{2}, 40 \mathrm{~mm} \mathrm{KCl,} 25 \mathrm{~mm}$ dNTPs, $1 \mu \mathrm{g}$ Oligo-dt [Gibco BRL], $1 \mathrm{~mm}$ DTT, $1 \mathrm{U}$ RNase inhibitor (Boehringer, Mannheim, Germany), and $10 \mathrm{U}$ SuperScript II [Gibco, BRL]) at $42^{\circ} \mathrm{C}$ for 2 hours. The PCR was carried out in a final volume of 50 $\mu \mathrm{L}$ containing $2 \mu \mathrm{L}$ of the single-strand cDNA product, $10 \mathrm{~mm}$ Tris- $\mathrm{HCl}$ (pH 9.0), $5 \mathrm{~mm} \mathrm{KCl,} 5 \mathrm{~mm} \mathrm{MgCl}, 0.2$ mм dATP, 0.2 mM dCTP, 0.2 mM dGTP, 0.2 mm dTTP, 2.5 U Taq DNA polymerase (Perkin Elmer, San Jose, California), and $20 \mathrm{pm}$ each of both the sense and the antisense primers.

To allow a quantitative determination of relative gene expression levels, the cDNA content of the samples was normalized, and the linear range of amplification was determined for each primer set. For each experiment the housekeeping gene GAPDH was amplified with 20 to 30 cycles to normalize the cDNA content of the samples. Equal cDNA amounts were subsequently used for the amplification of specific genes. The amplification was performed at $94^{\circ} \mathrm{C}(1$ minute), $60^{\circ} \mathrm{C}$ (2 minutes), and $72^{\circ} \mathrm{C}$ (3 minutes) for 24 to 30 cycles. The specific primers for human and rodent nAChR subunits $\alpha 3, \alpha 5, \alpha 7, \beta 2$, and $\beta 4$; the cell cycle regulators p21, p53, Ki-67, cyclin D1, PCNA, and PCNA; and the keratinocyte differentiation markers filaggrin, loricrin, CK 1 , and CK 10 are shown in Tables 2 and 3 . For quantitative determination of the relative gene expression levels, the $20-\mu \mathrm{L}$ samples were collected during PCR after the completion of three different cycle numbers in a linear range. The amplicons were analyzed on a $2 \%$ Sea Kem LE agarose gel (FMC, Riceland, Maine) stained with ethidium bromide. Pictures of the bands were taken using a digital imaging system (Alpha Imager 2000, San Leandro, California). Band intensities were determined by area integration. The experimental (exposed) samples were always run in parallel with control (nonexposed) samples. In each experiment, the relative gene expression level was determined after at least two different cycle numbers in a linear range and then averaged. To standardize the analysis, the results were expressed as a ratio of the gene expression level in an experimental sample compared with that in a control sample. To obtain this ratio, the intensity of the band in the experimental sample was divided by the value obtained in the control sample, and the results 
from three independent experiments were averaged. Therefore, the gene expression ratio in the control samples is always equal to 1. Negative controls included (a) omission of the RT step and (b) blank samples consisting of reaction mixtures without RNA, both of which were run in parallel with experimental samples.

\section{Western Blot Assay}

Proteins were isolated from the phenol ethanol supernatant by adding $1.5 \mathrm{~mL}$ of isopropyl alcohol per $1 \mathrm{~mL}$ of TRIzol Reagent used for the initial homogenization of OKC cultures or oral tissues of experimental animals. Protein pellets were washed three times with 2 $\mathrm{mL}$ of $0.3 \mathrm{M}$ guanidine hydrochloride in $95 \%$ ethanol and then one time with $2 \mathrm{~mL}$ of $95 \%$ ethanol. The pellets were dissolved in a sample application buffer (1.0 mL of 0.5 M Tris- $\mathrm{HCl}$ [pH 6.8], $1.9 \mathrm{~g}$ ultra pure urea [Fisher Scientific, Tustin, California], and 10\% SDS [Fisher Scientific]). Proteins were separated in 4\% to $15 \%$ SDS-PAGE, electroblotted onto a $0.2-\mu \mathrm{m}$ nitrocellulose membrane (Bio-Rad, Hercules, California), and blocked overnight at $4^{\circ} \mathrm{C}$ in the blocking buffer consisting of $5 \%$ nonfat dried milk in $0.1 \%(\mathrm{v} / \mathrm{v})$ Tween 20 (Sigma Chemical Co.), 25 mm Tris-HCl (pH 8), 125 $\mathrm{mm} \mathrm{NaCl}$, and $0.05 \%$ sodium azide. The primary antibodies were diluted in the blocking buffer and incubated for 1 hour at room temperature. The specificity and the dilutions of primary antibodies used and their sources are listed in Table 5. The secondary antibodies (sheep anti-mouse or donkey anti-rabbit Ig labeled with HRP [Amersham Pharmacia Biotech, Inc., Piscataway, New Jersey]) were diluted 1:3000 in the blocking buffer lacking sodium azide and applied to the membrane for 1 hour at room temperature. The membranes were developed using the ECL + Plus chemiluminescent detection system (Amersham Pharmacia Biotech, Inc.). To visualize antibody binding, the membranes were scanned with Fluorlmager/Storm ${ }^{\mathrm{TM}}$
(Molecular Dynamics, Mountain View, California), and the intensity of bands was analyzed using ImageQuant software (Molecular Dynamics). The results were standardized by expressing the density of each protein band under investigation in the experimental (exposed) sample relative to the value determined in the control (nonexposed) sample. The ratios obtained in three independent experiments were averaged to obtain the mean value. The specificity of staining was controlled in negative control experiments, in which the anti-peptide antiserum was preincubated with the specific peptide used for immunization, or the primary antibody was either omitted or replaced with an irrelevant, isotype- and species-matching antibody.

\section{IIF Assay}

The IIF experiments with oral tissues from experimental and control rodents were performed as detailed previously (Ndoye et al, 1998; Zia et al, 1997) using computerassisted image analysis with a software package purchased from Scanalytics (Fairfax, Virginia). The intensity of fluorescence was calculated pixel by pixel by dividing the summation of the fluorescence intensity of all pixels by the area occupied by the pixels (ie, segment) and then subtracting the mean intensity of fluorescence of a tissue-free segment (ie, background). For each tissue specimen, a minimum of three different segments in at least three different microscopic fields was analyzed, and the results were compared. To visualize membraneassociated molecules, such as nAChR subunits, the specimens were fixed for 3 minutes with $3 \%$ fresh depolymerized paraformaldehyde that contained $7 \%$ sucrose to avoid cell permeabilization. To visualize molecules located intracellularly, such as CK 10, oral tissue sections were permeabilized with $100 \%$ acetone for 10 minutes. The fixed specimens were washed and incubated overnight at $4^{\circ} \mathrm{C}$ with a primary antibody (Table 5). Binding of primary antibody was visualized by incubating the specimens for 1 hour at room temperature with

Table 5. The Primary Antibodies Used in This Study

\begin{tabular}{|c|c|c|c|c|c|}
\hline Antibody & Isotype & Host & Dilution $(\mu \mathrm{g} / \mathrm{mL})$ & Epitope & Reactivity \\
\hline$\alpha 3 \mathrm{nAChR}^{a}$ & $\lg G$ & Rabbit & 1 & CPLMAREDA & Human and rodent \\
\hline$\alpha 5 \mathrm{nAChR}^{a}$ & $\lg G$ & Rabbit & 1 & CPVHIGNANK & Same \\
\hline$\alpha 7 \mathrm{nAChR}^{a}$ & $\lg G$ & Rabbit & 1 & CFVEAVSKDFA & Same \\
\hline$\beta 2 \mathrm{nAChR}^{a}$ & $\lg G$ & Rabbit & 1 & CHSDHSAPSSK & Same \\
\hline$\beta 4 \mathrm{nAChR}^{a}$ & $\lg G$ & Rabbit & 1 & CEGPYAAQRD & Same \\
\hline$p 53^{b}$ & $\lg \mathrm{G} 1$ & Mouse & 5 & RHSVV & Same \\
\hline $\mathrm{p} 21^{b}$ & $\lg G 1$ & Mouse & 1 & TSMTDFYHSKRR & Same \\
\hline $\mathrm{Ki}-67^{b}$ & $\lg G 1$ & Mouse & 1 & 2597-2896 & Same \\
\hline Cyclin $\mathrm{D} 1^{b}$ & $\lg G 2$ & Mouse & 1 & 1-295 (whole protein) & Same \\
\hline PCNA $^{b}$ & $\lg G 2$ & Mouse & 2.5 & $112-121$ & Same \\
\hline $\operatorname{CK} 1^{c}$ & $\lg G$ & Rabbit & 0.4 & SSVKFCSTTYSGVTRC & Same \\
\hline $\mathrm{CK} 10^{c}$ & $\lg G$ & Rabbit & 1 & SGTGGGDQSSKGPNY & Same \\
\hline Filaggrin $^{c}$ & $\lg G$ & Rabbit & 0.5 & DSQVHSGVQVEGRRGH & Same \\
\hline Loricrin $^{c}$ & $\lg G$ & Rabbit & 1 & HQTQQKQAPTWPCK & Same \\
\hline
\end{tabular}

\footnotetext{
${ }^{a}$ Research \& Diagnostic Antibodies, Benicia, California.

${ }^{b}$ Oncogene Research Products, Boston, Massachusetts.

${ }^{c}$ BAbCO, Richmond, California.
} 
the appropriate secondary, fluorescein isothiocyanateconjugated antibody purchased from Pierce (Rockford, Illinois). The specimens were examined with an Axiovert 135 fluorescence microscope (Carl Zeiss, Inc., Thornwood, New York). The specificity of antibody binding in IIF experiments was demonstrated by omitting the primary antibody or by replacing primary antibody with an irrelevant antibody of the same isotype and species as the primary antibody.

\section{Radioligand Binding Experiments}

The nAChR binding studies were performed using the radioligand $(-)\left[\mathrm{N}-\right.$ metyl $\left.{ }^{3} \mathrm{H}\right] \mathrm{Nic}$ with a specific activity of $84.0 \mathrm{Ci} / \mathrm{mmol}$ (Amersham Pharmacia Biotech, Inc.) in monolayers of experimental (exposed to $\mathrm{Nic}$ ) and control (nonexposed) human OKC. The OKC were seeded into 24-well cell and tissue culture plates (Becton Dickinson, Franklin Lakes, New Jersey) at a density of $1 \times 10^{5}$ cells per well and incubated overnight in a $5 \% \mathrm{CO}_{2}$ incubator at $37^{\circ} \mathrm{C}$ to allow the cells to settle and attach to the dish bottom. Then, the wells were washed to remove nonattached cells, and the monolayers were exposed to KGM containing 10 $\mu \mathrm{M} \mathrm{Nic}$, alone or in combination with $50 \mu \mathrm{M} \mathrm{Mec}$, versus no additions in the controls. The plates were returned to the $\mathrm{CO}_{2}$ incubator. After a 24-hour incubation, the monolayers were washed thoroughly with warm $\left(37^{\circ} \mathrm{C}\right)$ PBS and used in a standard whole-cell radioligand binding assay, as detailed by us previously (Grando et al, 1995). Briefly, 100- $\mu \mathrm{L}$ aliquots of PBS containing increasing concentrations of $\left[{ }^{3} \mathrm{H}\right] \mathrm{Nic}$, from 0.1 to $100.0 \mathrm{~nm}$, were added to the triplicate wells, and the binding was allowed to reach equilibrium during a 4-hour incubation at $4^{\circ} \mathrm{C}$. The nonspecific binding was determined in the presence of $100 \mu \mathrm{M}$ Mec. The nonbound radioligand was removed by thorough washing with ice-cold PBS. The monolayers were solubilized in $1 \%$ SDS, the aliquots were mixed with scintillation cocktail, and the radioactivity was measured in an automated scintillation $\beta$-counter (Wallac, Gaithersburg, Maryland). Saturation isotherms were analyzed by nonlinear regression with Prism software (Graph-Pad Software, San Diego, California). The results were expressed both per cell and per milligram of cell protein. The protein concentration was determined at the end of each experiment in the replicas of experimental and control monolayers using the Bradford assay (Bio-Rad).

\section{Acknowledgements}

We are grateful to Ms. Marzieh Shafii for help with the animal ADSS exposure experiments.

\section{References}

Andersson G, Axell T, and Larsson A (1989). Histologic changes associated with the use of loose and portion-bag packed Swedish moist snuff: A comparative study. J Oral Pathol Med 18:491-497.
Bartek J, Staskova Z, Draetta G, and Lukas J (1993). Molecular pathology of the cell cycle in human cancer cells. Stem Cells 11(Suppl 1):51-58.

Benowitz NL (1986). Clinical pharmacology of nicotine. Annu Rev Med 37:21-32.

Benowitz NL (1997). Systemic absorption and effects of nicotine from smokeless tobacco. Adv Dent Res 11:336-341.

Benowitz NL and Gourlay SG (1997). Cardiovascular toxicity of nicotine: Implications for nicotine replacement therapy. J Am Coll Cardiol 29:1422-1431.

Booyse FM, Osikowicz G, and Quarfoot AJ (1981). Effects of chronic oral consumption of nicotine on the rabbit aortic endothelium. Am J Pathol 102:229-238.

Boring CC, Squires TS, Tong T, and Montgomery S (1994). Cancer statistics. CA Cancer J Clin 44:7-26.

Brinton LA, Blot WJ, Becker JA, Winn DM, Browder JP, Farmer JC Jr, and Fraumeni JF Jr (1984). A case-control study of cancers of the nasal cavity and paranasal sinuses. Am J Epidemiol 119:896-906.

Chen YP, Johnson GK, and Squier CA (1994). Effects of nicotine and tobacco-specific nitrosamines on hamster cheek pouch and gastric mucosa. J Oral Pathol Med 23:251255 .

Chomczynski P and Sacchi N (1987). Single-step method of RNA isolation by acid guanidinium thiocyanate-phenolchloroform extraction. Anal Biochem 162:156-159.

Connolly GN, Winn DM, Hecht SS, Henningfield JE, Walker B $\mathrm{Jr}$, and Hoffmann D (1986). The reemergence of smokeless tobacco. N Engl J Med 314:1020-1027.

Conti-Tronconi BM, McLane KE, Raftery MA, Grando SA, and Protti MP (1994). The nicotinic acetylcholine receptor: Structure and autoimmune pathology. Crit Rev Biochem Mol Biol 29:69-123.

Daniels TE, Hansen LS, Greenspan JS, Grady DG, Hauck WW, Greene JC, and Ernster VL (1992). Histopathology of smokeless tobacco lesions in professional baseball players. Associations with different types of tobacco. Oral Surg Oral Med Oral Pathol 73:720-725.

Delbono O, Gopalakrishnan M, Renganathan M, Monteggia LM, Messi ML, and Sullivan JP (1997). Activation of the recombinant human $\alpha 7$ nicotinic acetylcholine receptor significantly raises intracellular free calcium. J Pharmacol Exp Ther 280:428-438.

El-Deiry WS, Tokino T, Velculescu VE, Levy DB, Parsons R, Trent JM, Lin D, Mercer WE, Kinzler KW, and Vogelstein B (1993). WAF1, a potential mediator of p53 tumor suppression. Cell 75:817-825.

Ellis RE, Yuan JY, and Horvitz HR (1991). Mechanisms and functions of cell death. Annu Rev Cell Biol 7:663-698.

Fieber LA and Adams DJ (1991). Acetylcholine-evoked currents in cultured neurons dissociated from rat parasympathetic cardiac ganglia. J Physiol 434:215-238.

Gerzanich V, Wang F, Kuryatov A, and Lindstrom J (1998). $\alpha 5$ subunit alters desensitization, pharmacology, $\mathrm{Ca}^{++}$permeability and $\mathrm{Ca}^{++}$modulation of human neuronal $\alpha 3$ nicotinic receptors. J Pharmacol Exp Ther 286:311-320.

Grady D (1998). Nicotine's image takes a turn for the worse. The New York Times, November 17, 1998:D1, D8. 
Grando SA (1997). Biological functions of keratinocyte cholinergic receptors. J Investig Dermatol Symp Proc 2:41-48.

Grando SA, Crosby AM, Zelickson BD, and Dahl MV (1993). Agarose gel keratinocyte outgrowth system as a model of skin re-epithelization: Requirement of endogenous acetylcholine for outgrowth initiation. J Invest Dermatol 101:804810.

Grando SA, Horton RM, Mauro TM, Kist DA, Lee TX, and Dahl MV (1996). Activation of keratinocyte nicotinic cholinergic receptors stimulates calcium influx and enhances cell differentiation. J Invest Dermatol 107:412-418.

Grando SA, Horton RM, Pereira EFR, Diethelm-Okita BM, George PM, Albuquerque EX, and Conti-Fine BM (1995). A nicotinic acetylcholine receptor regulating cell adhesion and motility is expressed in human keratinocytes. J Invest Dermatol 105:774-781.

Hall BK, Lee A, and Squier CA (1984). Morphological effects of nicotine and ethanol on oral mucosa. J Dent Res 63:262.

Heeschen C, Jang JJ, Weis M, Pathak A, Kaji S, Hu RS, Tsao PS, Johnson FL, and Cooke JP (2001). Nicotine stimulates angiogenesis and promotes tumor growth and atherosclerosis. Nat Med 7:833-839.

Hirsch JM, Heyden G, and Thilander H (1982). A clinical, histomorphological and histochemical study on snuffinduced lesions of varying severity. J Oral Pathol 11:387-398.

Horster M, Brechtelsbauer $\mathrm{H}$, Wilson $\mathrm{P}$, and Schmolke $\mathrm{M}$ (1984). Effects of nicotine on epithelial nephron cells in culture. Klin Wochensch 62(Suppl 2):86-91.

Hory-Lee F and Frank E (1995). The nicotinic blocking agents $\mathrm{d}$-tubocurare and $\alpha$-bungarotoxin save motoneurons from naturally occurring death in the absence of neuromuscular blockade. J Neurosci 15:6453-6460.

Hunter T and Pines J (1994). Cyclins and cancer. II. Cyclin D and CDK inhibitors come of age. Cell 79:573-582.

Ji CM, Royce FH, Truong U, Plopper CG, Singh G, and Pinkerton KE (1998). Maternal exposure to environmental tobacco smoke alters Clara cell secretory protein expression in fetal rat lung. Am J Physiol 275:L870-L876.

Joad JP, Ji C, Kott KS, Bric JM, and Pinkerton KE (1995). In utero and postnatal effects of sidestream cigarette smoke exposure on lung function, hyperresponsiveness, and neuroendocrine cells in rats. Toxicol Appl Pharmacol 132:63-71.

Joad JP, Pinkerton KE, and Bric JM (1993). Effects of sidestream smoke exposure and age on pulmonary function and airway reactivity in developing rats. Pediatr Pulmonol 16:281-288.

Johnson GK and Squier CA (1993). Smokeless tobacco use by youth: A health concern. Pediatr Dent 15:169-174.

Kaugars GE, Mehailescu WL, and Gunsolley JC (1989). Smokeless tobacco use and oral epithelial dysplasia. Cancer 64:1527-1530.

Kwon OS, Chung JH, Cho KH, Suh DH, Park KC, Kim KH, and Eun HE (1999). Nicotine-enhanced epithelial differentiation in reconstructed human oral mucosa in vitro. Skin Pharmacol Appl Skin Physiol 12:227-234.

Lane DP and Benchimol S (1990). p53: Oncogene or antioncogene? Genes Dev 4:1-8.

Liebermann DA, Hoffman B, and Steinman RA (1995). Molecular controls of growth arrest and apoptosis: p53- dependent and independent pathways. Oncogene 11:199210.

Lindell G, Farnebo LO, Chen D, Nexo E, Rask Madsen J, Bukhave K, and Graffner H (1993). Acute effects of smoking during modified sham feeding in duodenal ulcer patients an analysis of nicotine acid secretion gastrin catecholamines epidermal growth factor prostaglandin E-2 and bile acids. Scand J Gastroenterol 28:487-494.

Luomanen M, Tiitta O, Heikinheimo K, Heinaro I, and Happonen RP (1997). Effect of snuff on cytokeratin expression in oral vestibular sulcus epithelium. J Oral Pathol Med 26:110116.

MacCallum DE and Hall PA (1999). Biochemical characterization of pKi67 with the identification of a mitotic-specific form associated with hyperphosphorylation and altered DNA binding. Exp Cell Res 252:186-198.

Miyashita T and Reed JC (1995). Tumor suppressor p53 is a direct transcriptional activator of the human bax gene. Cell 80:293-299.

Mulle C, Choquet D, Korn H, and Changeux JP (1992). Calcium influx through nicotinic receptor in rat central neurons: Its relevance to cellular regulation. Neuron 8:135143.

Ndoye A, Buchli R, Greenberg B, Nguyen VT, Zia S, Rodriguez JG, Webber RJ, Lawry MA, and Grando SA (1998). Identification and mapping of keratinocyte muscarinic acetylcholine receptor subtypes in human epidermis. J Invest Dermatol 111:100-106.

Nguyen VT, Hall LL, Gallacher G, Ndoye A, Jolkovsky DL, Webber RJ, Buchli R, and Grando SA (2000a). Choline acetyltransferase, acetylcholinesterase, and nicotinic acetylcholine receptors of human gingival and esophageal epithelia. J Dent Res 79:939-949.

Nguyen VT, Ndoye A, and Grando SA (2000b). Novel human $\alpha 9$ acetylcholine receptor regulating keratinocyte adhesion is targeted by pemphigus vulgaris autoimmunity. Am J Pathol 157:1377-1391.

Ogle CW and Glavin GB (1996). Chronic nicotine treatment upregulates muscarinic M1-receptors in the rat stomach. Med Sci Res 24:83-84.

Oh JS, Cherrick HM, and Park NH (1990). Effect of snuff extract on the replication and synthesis of viral DNA and proteins in cells infected with herpes simplex virus. J Oral Maxillofac Surg 48:373-380.

Orr-Urtreger A, Broide RS, Kasten MR, Dang H, Dani JA, Beaudet AL, and Patrick JW (2000). Mice homozygous for the L250T mutation in the alpha7 nicotinic acetylcholine receptor show increased neuronal apoptosis and die within 1 day of birth. J Neurochem 74:2154-2166.

Peacock ME, Sutherland DE, Schuster GS, Brennan WA, O'Neal RB, Strong SL, and Van Dyke TE (1993). The effect of nicotine on reproduction and attachment of human gingival fibroblasts in vitro. J Periodontol 64:658-665.

Pittilo RM, Bull HA, Gulati S, Rowles PM, Blow CM, Machin SJ, and Woolf N (1990). Nicotine and cigarette smoking: Effects on the ultrastructure of aortic endothelium. Int J Exp Pathol 71:573-586.

Poluha W, Schonhoff CM, Harrington KS, Lachyankar MB, Crosbie NE, Bulseco DA, and Ross AH (1997). A novel, nerve growth factor-activated pathway involving nitric oxide, p53, 
and p21waf1 regulates neuronal differentiation of PC12 cells. J Biol Chem 272:24002-24007.

Quik M, Philie J, and Choremis J (1997). Modulation of $\alpha 7$ nicotinic receptor-mediated calcium influx by nicotinic agonists. Mol Pharmacol 51:499-506.

Ringdahl BE, Johnson GK, Ali RB, and Organ CC (1997). Effect of nicotine on arachidonic acid metabolites and epithelial parameters in rat oral mucosa. J Oral Pathol Med 26:40-45.

Russell MA, Jarvis M, lyer R, and Feyerabend C (1980). Relation of nicotine yield of cigarettes to blood nicotine concentrations in smokers. Br Med J 280:972-976.

Russell MA, Jarvis MJ, Devitt G, and Feyerabend C (1981). Nicotine intake by snuff users. Br Med J 283:814-817.

Sastry BVR (1995). Neuropharmacology of nicotine: Effects on the autoregulation of acetylcholine release by substance $P$ and methionine enkephalin in rodent cerebral slices and toxicological implications. Clin Exp Pharmacol Physiol 22: 288-290.

Schuller HM, McGavin MD, Orloff M, Riechert A, and Porter B (1995). Simultaneous exposure to nicotine and hyperoxia causes tumors in hamsters. Lab Invest 73:448-456.

Sonenberg N, Hershey JWB, and Mathews MB (2000). Translational control of gene expression, vol 39. New York: Cold Spring Harbor Laboratory Press, 1-1020.

Steinbach JH (1990). Mechanism of action of the nicotinic acetylcholine receptor. In: Bock $\mathrm{G}$ and Marsh J, editors. The biology of nicotine dependence (proceedings of a symposium held at the Ciba Foundation, London, November 7-9, 1989). New York: John Wiley and Sons Ltd., 53-61.

Sugar J, Vereczkey I, and Toth J (1996). Some etiopathogenetic factors in laryngeal carcinogenesis. J Environ Pathol Toxicol Oncol 15:195-199.

Sundstrom B, Mornstad H, and Axell T (1982). Oral carcinomas associated with snuff dipping. Some clinical and histological characteristics of 23 tumours in Swedish males. J Oral Pathol 11:245-251.

Teague SV, Pinkerton KE, Goldsmith M, Gebremichael A, Chang S, Jenkins RA, and Moneyhun JH (1994). Sidestream cigarette smoke generation and exposure system for environmental tobacco smoke studies. Inhalation Toxicol 6:7993.

Theilig C, Bernd A, Ramirez-Bosca A, Gormar FF, BereiterHahn J, Keller-Stanislawski B, Sewell AC, Rietbrock N, and Holzmann H (1994). Reactions of human keratinocytes in vitro after application of nicotine. Skin Pharmacol 7:307-315.

Tominaga K, Hato F, Kinoshita Y, Tominaga M, and Yamada M (1992). Enhancement of DNA synthesis in rat thymocytes by stimulating their muscarinic acetylcholine receptors. Cell Mol Biol 38:815-822.
Toth E, Vizi ES, and Lajtha A (1993). Effect of nicotine on levels of extracellular amino acids in regions of the rat brain in vivo. Neuropharmacology 32:827-832.

Tsurimoto T (1999). PCNA binding proteins. Front Biosci 4:849-858.

van Oijen MG, Gilsing MM, Rijksen G, Hordijk GJ, and Slootweg PJ (1998). Increased number of proliferating cells in oral epithelium from smokers and ex-smokers. Oral Oncol 34:297-303.

van Oijen MG, van de Craats JG, and Slootweg PJ (1999). p53 overexpression in oral mucosa in relation to smoking. J Pathol 187:469-474.

Villablanca AC (1998). Nicotine stimulates DNA synthesis and proliferation in vascular endothelial cells in vitro. J Appl Physiol 84:2089-2098.

Walsh K (1997). Coordinate regulation of cell cycle and apoptosis during myogenesis. Prog Cell Cycle Res 3:53-58.

Wang H (1997). Modulation by nicotine on muscarinic receptor-effector systems. Chung Kuo Yao Li Hsueh Pao 18:193-197.

Waseem NH and Lane DP (1990). Monoclonal antibody analysis of the proliferating cell nuclear antigen (PCNA). Structural conservation and the detection of a nucleolar form. J Cell Sci 96:121-129.

Wedenberg C, Jonsson A, and Hirsch JM (1996). Assessment of p53 and Ki-67 expression in snuff-induced lesions. $\mathrm{Br} \mathrm{J}$ Oral Maxillofac Surg 34:409-413.

Weintraub JA and Burt BA (1987). Periodontal effects and dental caries associated with smokeless tobacco use. Public Health Rep 102:30-35.

Wells AB and Lamerton LF (1975). Regenerative response of the rat tracheal epithelium after acute exposure to tobacco smoke: A quantitative study. J Natl Cancer Inst 55:887-891.

Zevin S, Gourlay SG, and Benowitz NL (1998). Clinical pharmacology of nicotine. Clin Dermatol 16:557-564.

Zia S, Ndoye A, Lee TX, Webber RJ, and Grando SA (2000). Receptor-mediated inhibition of keratinocyte migration by nicotine involves modulations of calcium influx and intracellular concentration. J Pharmacol Exp Ther 293:973-981.

Zia S, Ndoye A, Nguyen VT, and Grando SA (1997). Nicotine enhances expression of the $\alpha 3, \alpha 4, \alpha 5$, and $\alpha 7$ nicotinic receptors modulating calcium metabolism and regulating adhesion and motility of respiratory epithelial cells. Res Commun Mol Pathol Pharmacol 97:243-262.

Zimmerman M and McGeachie J (1987). The effect of nicotine on aortic endothelium. A quantitative ultrastructural study. Atherosclerosis 63:33-41. 